\title{
Reports
}

\section{Market Economy and the Loss of Folk Knowledge of Plant Uses: Estimates from the Tsimane' of the Bolivian Amazon ${ }^{1}$}

\author{
VICTORIA REYES-GARCÍA, VINCENT VADEZ, \\ ELIZABETH BYRON, LILIAN APAZA, WILLIAM R. \\ LEONARD, EDDY PEREZ, AND DAVID WILKIE \\ Sustainable International Development Program, \\ Heller School for Social Policy and Management, \\ Brandeis University, Waltham, MA 02454-9IIO, \\ U.S.A. (vreyes@brandeis.edu) (Reyes-García and \\ Vadez)/International Food Policy Research Institute, \\ Washington, DC 20006-I002, U.S.A. (Byron)/ \\ Protección del Medio Ambiente Tarija, Calle \\ Alejandro del Carpio $N^{\mathrm{a}}$ E-0659, Casilla $N^{\circ}$ 59, Bolivia \\ (Apaza)/Department of Anthropology, Northwestern \\ University, Evanston, IL 60208, U.S.A. (Leonard)/ \\ Fundación para el Desarrollo de la Ecologia, Estación \\ Biológica Tunquini, Bolivia (Pérez)/Wildlife \\ Conservation Society, I8 Clark Lane, Waltham, MA \\ 0245I-I823, U.S.A. (Wilkie). IO II O5
}

For most of human history, people's main form of knowledge has been adapted to the local environment and based on experience and empirical testing. This form of knowledge has been called folk or traditional knowledge (Conklin I954, Atran and Douglas I997, Berlin I992, Berkes, Colding, and Folke 2000). The disappearance of folk knowledge represents the irreversible loss of humanity's heritage and diversity (Sillitoe I998, Maffi 200I). Here we assess whether market economies contribute to the loss of folk knowledge of plant uses. We draw on information from Tsimane', a foraging-horticultural society in the Bolivian Amazon, to estimate the correlation between participation in a market economy and folk knowledge of plant uses.

Since the I980s anthropologists have used agreement among informants as a proxy for knowledge to study pat-

(C) 2005 by The Wenner-Gren Foundation for Anthropological Research. All rights reserved OOI I-3204/2005/4604-0007\$IO.00

I. Research was funded by grants from the National Science Foundation (SBR-973 I 240 and SBR-99043 I 8), the John D. and Catherine T. MacArthur Foundation, and the Conservation, Food and Health Foundation. We thank S. Tanner, Z. Foster, B. Sandstrom, Y. Gutierrez, M. Alvarado, T. Huanca, D. Ista, J. Pache, A. Nate, P. Pache, E. Tayo, M. Roca, and Gran Consejo Tsimane' for data collection and logistical support. We thank R. Bernard, S. Brush, R. Godoy, J. L. Molina, M. Schmink, B. Orlove, P. Sillitoe, J. Stepp, V. Toledo, and three reviewers for comments. terns of knowledge distribution within a group. Researchers have found that older people, women, and people related by kinship share more knowledge of plant uses (Boster 1986, Caniago and Siebert I998, Garro I986). Researchers have also studied the effects of the market economy on knowledge of plant uses. Among the many factors that could contribute to the loss of folk knowledge of plant uses, the market economy may play a role because markets allow access to substitutes for products made from plants (Locay I989). Also, the development of market economies tends to be correlated with greater socioeconomic heterogeneity, and therefore one might expect greater variance in plant knowledge as markets expand.

So far, research estimating the link between socioeconomic variables and a person's folk knowledge has produced unclear results. Some researchers have shown a negative correlation between skills associated with the market and folk knowledge. In a study in Mexico, Benz et al. (2000) found a negative correlation between knowledge of plant uses and skills in Spanish. In a study of 85 children in a rural village in Kenya, Sternberg et al. (200I) found that scores on a test of tacit knowledge were negatively correlated with math scores. Zent (200I) found a negative correlation between knowledge of forest trees and either schooling or fluency in spoken Spanish among IO4 Amerindians in Venezuela. Others have found that markets do not always erode folk knowledge. In a study with 80 adult Amerindians in Honduras, Godoy et al. (I998) found that integration into the market through sale of crops or wage labor was correlated with less knowledge of wildlife but integration into the market through the sale of forest goods was correlated with more knowledge of wildlife. In two cross-sectional surveys spanning 30 years among Maya children in Mexico, Zarger and Stepp (2004) found no change in plant knowledge despite significant socioeconomic changes in the region.

Most of the studies just reviewed used a small sample of observations and focused on a few covariates. We overcome these limitations by including a large number of observations and using many covariates that serve as proxies for different dimensions of integration into the market.

\section{METHODS}

Research lasted I8 months (May I999 to November 2000) and included repeated measures from the same informants of two villages (panel survey) and a one-time survey in 59 villages spread throughout the Tsimane' territory (cross-sectional survey).

Study site. The Tsimane' are a foraging-horticulturalist group of about 8,000 people living in some Ioo villages in the department of Beni, in the Bolivian Amazon. In the past 25 years, the opening of a new road and the boom in the exploitation of precious wood species have 


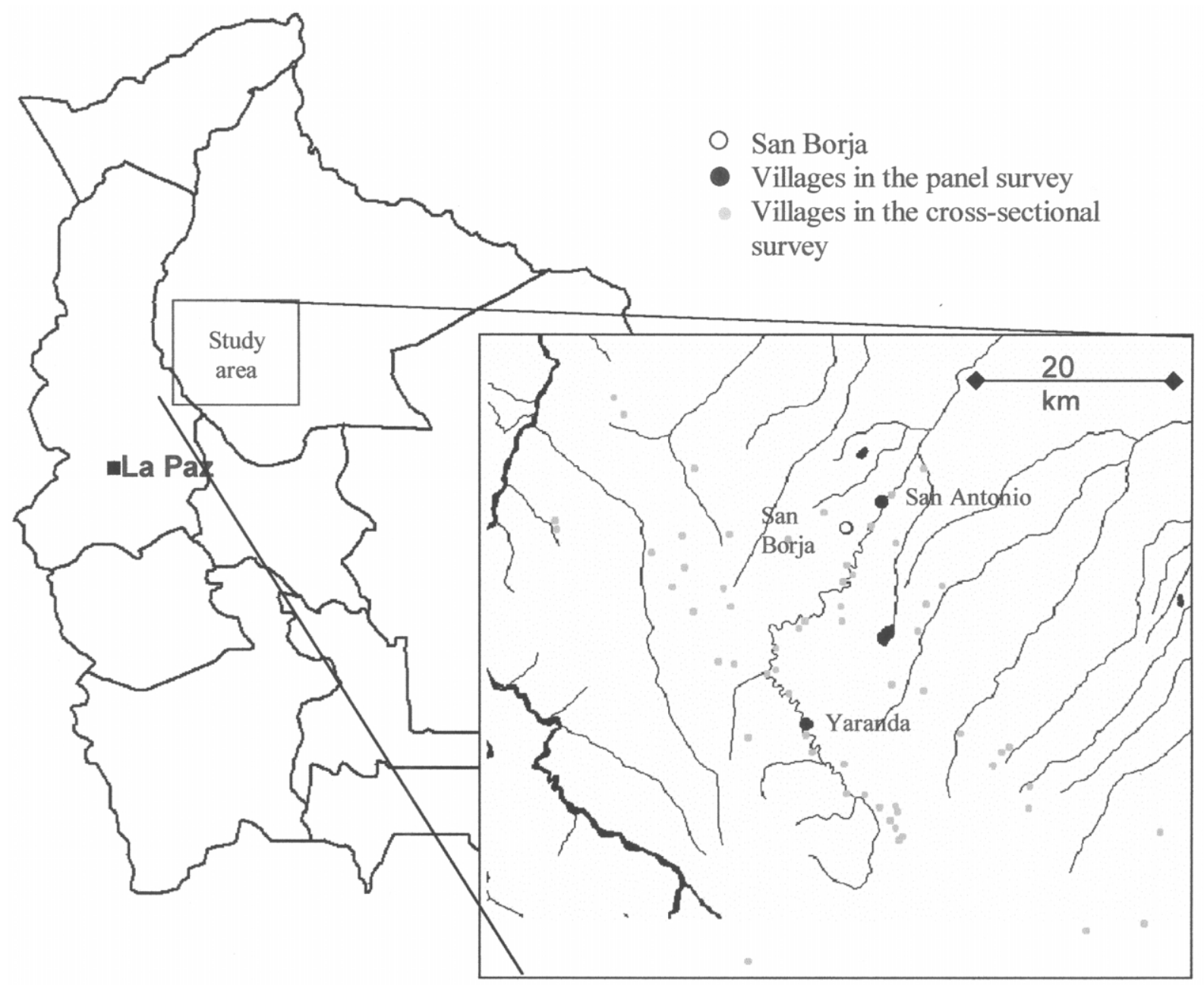

FIG. I. Bolivia and the study area, showing the market town (San Borja), the villages in the panel survey (Yaranda and San Antonio), and the villages in the cross-sectional survey.

provided options for the Tsimane' to enter the market economy in two main ways. Tsimane' living far from towns swap thatch palm for commercial goods, an activity that increases their dependence on the forest. Tsimane' closer to towns earn cash from selling crops and from working for highland colonist farmers and cattle ranchers, activities that decrease their dependence on the forest (Godoy 200I, Vadez et al. 2004). Because Tsimane' vary in the frequency and intensity of contact with the market economy, they are ideal subjects for a study of the effects of the market on folk knowledge of plants.

Sample. We selected villages that varied in distance from the closest town. The panel study was conducted in the villages of Yaranda, which is a three-day canoe trip from the closest market town, and San Antonio, which is a three-hour walk from the same town. We surveyed all the adults in the two villages $(n=$ I08) on three occasions $(n=3$ I 2$)$. The cross-sectional survey included 497 households in 59 villages (avg $=8.7$ house- holds surveyed/village, s.d. $=2.87$ ) (fig. I). In each household we randomly selected either the female or the male household head for the interview.

Estimation strategy. Folk knowledge reflects demographic attributes, socioeconomic variables that serve as proxies for acculturation and integration into the market, and attributes of the village and the habitat. We express knowledge as

$$
K_{i j v t}=\alpha+\beta X_{i j v t}+\gamma Y_{i j v t}+\theta Z_{v t}+\varepsilon_{i j v t}
$$

where $K_{i j v t}$ is the individual knowledge of informant $i$ of household $j$ in village $v$ at time $t . X_{i j v t}$ is a vector of variables that capture demographic and life-cycle attributes of the informant, $Y_{i j v t}$ is a vector of variables that serve as proxies for integration into the market, $Z_{v t}$ is a vector of variables that serve as proxies for the attributes of village $v$ at time $t$, and $\varepsilon_{i j v t}$ is a random error term. Village attributes are important because they may cap- 


\begin{tabular}{|c|c|c|c|c|c|}
\hline \multirow[b]{2}{*}{ Variables } & \multirow[b]{2}{*}{ Definition and Units } & \multicolumn{2}{|c|}{$\begin{array}{c}\text { Panel } \\
(n=3 \text { I } 2)\end{array}$} & \multicolumn{2}{|c|}{$\begin{array}{l}\text { Cross Section } \\
(n=497)\end{array}$} \\
\hline & & Mean & S.D. & Mean & S.D. \\
\hline \multicolumn{6}{|l|}{$\begin{array}{l}\text { Dependent: Cultural } \\
\text { competence }\end{array}$} \\
\hline Intravillage & $\begin{array}{l}\text { Agreement with the village } \\
(\mathrm{O}-\mathrm{I})\end{array}$ & 0.75 & O.I 5 & 0.64 & O.IO \\
\hline Pool & $\begin{array}{l}\text { Agreement with the entire } \\
\text { sample (O-I) }\end{array}$ & 0.80 & O.I 8 & $0.6 \mathrm{I}$ & 0.09 \\
\hline \multicolumn{6}{|c|}{ Explanatory: Market-related } \\
\hline Distance & $\begin{array}{l}\text { Village distance to the market } \\
\text { town }(\mathrm{km})\end{array}$ & & & 35 & 22 \\
\hline Cash & $\begin{array}{l}\text { Personal cash earnings from } \\
\text { wage labor and sale of prod- } \\
\text { ucts (US\$/adult/month) }\end{array}$ & IO & $2 \mathrm{I}$ & 30 & 45 \\
\hline Wealth & $\begin{array}{l}\text { Value of a stock of I } 3 \text { commer- } \\
\text { cial items owned by house- } \\
\text { hold (US\$) }\end{array}$ & $4 \mathrm{IO}$ & 272 & 260 & 246 \\
\hline \multicolumn{6}{|c|}{ Explanatory: Acculturation } \\
\hline Schooling & $\begin{array}{l}\text { Educational attainment (school } \\
\text { grade) }\end{array}$ & I. 5 & I.95 & 0.9 & I.63 \\
\hline Spanish & $\begin{array}{l}\text { Ability to communicate in } \\
\text { Spanish (o-2) }\end{array}$ & I.O & 0.74 & 0.8 & 0.66 \\
\hline Father's schooling & School grade & 0.42 & $\mathrm{I} .75$ & & \\
\hline \multicolumn{6}{|l|}{ Control } \\
\hline Age & Age in years & 34 & I 5 & 36 & I4 \\
\hline Male & Gender (male I, female o) & $0.5 \mathrm{I}$ & 0.5 & 0.52 & 0.5 \\
\hline
\end{tabular}

ture any ecological variation between villages that is correlated with knowledge; for example, some villages may contain greater biological diversity, and those villagers may have a greater repertoire of plant knowledge.

Dependent variable: Folk knowledge of plant uses. We used a cultural consensus model (Romney, Weller, and Batchelder I986) and proxy folk knowledge by calculating agreement among informants on responses to multiple-choice questions on plant uses. The merit of the method is that it allows one to measure folk knowledge over a large sample by using structured interviews. The method, however, has several shortcomings. It does not allow one to analyze factual use of plants or objective knowledge, and it works only if plant nomenclature does not vary across villages. Last, it does not capture specialized knowledge; it concentrates on general, commonly held knowledge. Thus, experts could score low on cultural competence because they give answers that others do not know (Boster and Johnson I989).

To get individual estimates of folk knowledge, we first generated a list of useful plants by using free listing from 50 subjects on the panel. From the 92 plants that were mentioned by at least one informant in each village, we developed three multiple-choice questionnaires. In the questionnaires we asked subjects whether plants could be used for none, one, or various of the following uses: building, firewood, food, medicine, canoes, and tools. We employed the three questionnaires in the panel survey (Reyes-García et al. 2004) and only one questionnaire in the cross-sectional survey. Surveys were conducted in Tsimane' with the help of translators. We used the answers to calculate the variables cultural consensus and cultural competence (table I). Cultural consensus is the group average similarity in responses and was calculated at the village level. Cultural competence is the proportion of questions coinciding with the most frequent response in the group and was calculated at the individual level.

Explanatory and control variables. We measured variables that serve as proxies for current and long-term participation in the market. Among the measures that captured current participation in the market we included distance from the closest market town, distance squared (to control for nonlinearity), and own cash earnings from wage labor and from the sale of goods. As a proxy for long-term participation in the market we measured gross household wealth, defined as the total monetary value of a basket of modern assets (e.g., a shotgun). We equated acculturation with schooling (measured by the maximum school grade attained by the informant) and fluency in spoken Spanish (as assessed by the interviewer). In the panel study we also collected data on the schooling of the informant's father to control for family-background characteristics. We used the subject's age and sex as controls.

Potential biases in estimations. All the variables that serve as proxies for integration into the market are potentially endogenous because we cannot control for unobserved heterogeneity in subject endowments and pref- 
erences. As a result, the parameters we estimate should be interpreted as correlations rather than as causal statements. For instance, people with less plant knowledge may have decided to move farther from the market town, and people with particular unobserved abilities may be more likely to learn about plants and gravitate toward (or move away from) the market. Still another source of endogeneity could stem from classic measurement errors of the variables involved.

\section{RESULTS}

Cultural consensus. In the panel study, we calculated cultural consensus for each village and questionnaire. All the answers fit the cultural consensus model, meaning that people agreed on the uses of plants. In the three questionnaires, the level of agreement was higher in the isolated village of Yaranda than in San Antonio (ratio of the first to the second eigenvalue $=37$ versus $2 \mathrm{I}$ on the first multiple-choice, 42 versus 26 on the second, and 42 versus ig on the third). Data from the cross-sectional study suggest that individuals in more isolated villages share more knowledge of plant uses than individuals in villages closer to town (fig. 2). In villages with more than eight informants $(n=29)$, we found a positive correlation between village cultural consensus and village-totown distance (coeff. $=0.46 ; p<0.01$ ).

Cultural competence in knowledge of plant uses: The panel survey. We next used data from the panel to explore whether people in a village know more or less as a function of their economic status. For the village closest to the market town, we did not find a relation between knowledge and cash or wealth. The three proxies for acculturation (informant's schooling, fluency in spoken
TABLE 2

Panel Survey: Market and Human-Capital Variables and Cultural Competence

\begin{tabular}{|c|c|c|c|}
\hline Variable & $\begin{array}{l}\text { San Antonio } \\
\quad(n=\mathrm{s} \\
\end{array}$ & $\begin{array}{l}\text { Yaranda }^{\mathrm{c}} \\
(n=\mathrm{I} 44)\end{array}$ & $\begin{array}{c}\text { Pool }^{\mathrm{b}} \\
(n=312)\end{array}$ \\
\hline \multicolumn{4}{|l|}{ Market-related } \\
\hline Yaranda $^{a}$ & & & $0.244^{* * * *}$ \\
\hline Cash (US\$IOo) & -0.037 & о.ого & -0.029 \\
\hline Wealth $($ US\$ $\$, 000)$ & $0.03 \mathrm{I}$ & $-0.042^{*}$ & 0.0001 \\
\hline \multicolumn{4}{|l|}{ Acculturation } \\
\hline School & $0.02 \mathrm{I}^{* * * *}$ & -0.003 & $0.014^{* * * *}$ \\
\hline Spanish $^{a}$ & $-0.054^{* *}$ & 0.0003 & $-0.04 \mathrm{I}^{*}$ \\
\hline Father's schooling ${ }^{a}$ & $-0.014^{* * * *}$ & -0.003 & $-0.013^{* * *}$ \\
\hline \multicolumn{4}{|l|}{ Control } \\
\hline Age (Io years) & $0.03 \mathrm{I}$ & $0.072^{* * * *}$ & $0.033^{*}$ \\
\hline Age squared & -0.002 & $-0.006^{* * *}$ & -0.002 \\
\hline Male $^{\mathrm{a}}$ & 0.026 & 0.001 & $0.02 \mathrm{I}$ \\
\hline
\end{tabular}

NOTE: Cells contain regression coefficients. Regressions contain a constant and binary variables for quarters (not shown). ${ }^{*} p \leq$ O. I; ${ }^{* *} p<0.05 ;{ }^{* * *} p<0.0$ I.


${ }^{\mathrm{b}}$ Random-effect regression with semirobust standard errors.

${ }^{\mathrm{c}}$ Ordinary least squares regression with robust standard errors.

Spanish, and father's schooling) were correlated with agreement in plant knowledge but not always in the expected direction (table 2). Contrary to our expectation, one additional year of schooling was correlated with 2.I\% higher agreement in plant knowledge $(p<0.0 \mathrm{I})$. Fluency in Spanish was correlated with $5.4 \%$ less agreement in plant knowledge $(p<0.05)$, and parental schooling was correlated with $\mathrm{I} .4 \%$ less agreement in plant knowledge $(p<$ o.or).

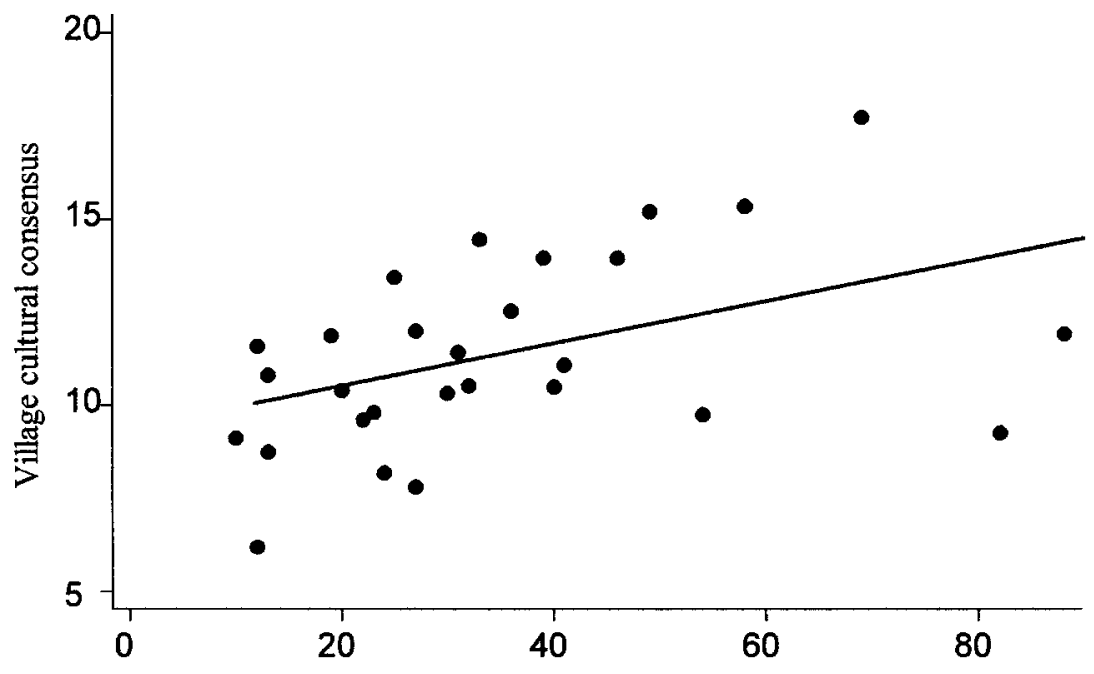

Distance from village to town $(\mathrm{km})$

Fig. 2. Cultural consensus and distance from closest market town (coef. $=0.46 ; \mathrm{p}<0.0 \mathrm{I} ; \mathrm{n}=29)$ in villages with more than eight informants. 
Volume 46, Number 4, August-October $2005 \mid 655$

In the more isolated village, cash income was not correlated with agreement in plant knowledge, but household wealth was correlated negatively with plant knowledge. An increase of US $\$ \mathrm{I}, 000$ in wealth was correlated with $4.2 \%$ lower agreement in plant uses $(p<0$. Io) (table 2). Age was also associated with more plant knowledge. An increase of ten years in a person's age was correlated with $7.2 \%$ higher agreement in plant knowledge $(p<$ o.or). We used a square term for age to control for possible nonlinearity. The negative coefficient of age squared shows that agreement in knowledge increases with age until about 55 years of age, after which agreement in knowledge declines.

We next pooled the answers from the two villages of the panel study and calculated the level of agreement of each informant with the entire sample. Village of residence yielded the most statistically significant result. Residing in the more isolated village was correlated with a $24.4 \%$ higher score in cultural competence $(p<0.00 \mathrm{I})$ (table 2). After controlling for village of residence, we found that neither cash nor wealth bore a statistically significant correlation with knowledge scores. Parameter estimates for acculturation variables produced mixed results. One more year of schooling was correlated with a I. $4 \%$ higher cultural competence score $(p<0.0 \mathrm{I})$, but fluency in Spanish was correlated with a $4.1 \%$ lower cultural competence score $(p<0$. Io). Parental schooling was correlated with a I.3\% lower score $(p<0.00 \mathrm{I})$, but ten more years of age was correlated with a $3.2 \%$ higher score $(p<$ O.I $)$.

Cultural competence in knowledge of plant uses: The cross-sectional survey. Though Tsimane' show a high level of agreement on plant uses (Reyes-García et al. 2003), agreement is likely to be higher with people of the same village than with people of other villages. To avoid this potential bias we analyzed the data in two ways. First we estimated cultural competence comparing individuals with people from their village (intravillage), and then we compared each individual with the entire sample (pool) (table 3).

Village-to-town distance was correlated with greater knowledge scores in a statistically significant way for both intravillage and pool scores. In both cases the link between folk knowledge and distance resembled an inverted $U$. When using intravillage agreement as a dependent variable, we found that people living $\mathrm{Io} \mathrm{km}$ away from the nearest town had $2.5 \%$ higher agreement in plant knowledge $(p<0.00 \mathrm{I})$, but people living farther than $48 \mathrm{~km}$ away from town had lower agreement in plant knowledge. Schooling was correlated with $2.4 \%$ higher scores in plant knowledge $(p<0.05)$, although fluency in Spanish was correlated with $2.7 \%$ lower scores $(p<0.05)$. Being a man was correlated with $2.5 \%$ higher scores $(p<0.01)$. We found similar results when using scores of knowledge of the pooled sample using village dummies to control for ecological variation. Each additional $\mathrm{ro} \mathrm{km}$ from the nearest town was correlated with $2.9 \%$ higher agreement in plant knowledge $(p<$ O.0oI). The apex of the inverted U curve was at $53 \mathrm{~km}$. An increase in age of ten years was correlated with $3.4 \%$
TABLE 3

Cross-sectional Survey: Market and Human-Capital Variables and Cultural Competence

\begin{tabular}{lcc}
\hline Variable & $\begin{array}{c}\text { Intravillage } \\
(n=340)\end{array}$ & $\begin{array}{c}\text { Pool }^{\mathrm{b}} \\
(n=497)\end{array}$ \\
\hline Market-related & & \\
Distance (in Io-km) & $0.025^{* * *}$ & $0.029^{* *}$ \\
Distance squared & $-0.003^{* * *}$ & $-0.003^{* * *}$ \\
Cash (US\$IOO) & 0.009 & 0.012 \\
Wealth (US\$I,000) & 0.022 & -0.023 \\
Acculturation & & \\
School & $0.024^{* *}$ & $0.015 \mathrm{I}$ \\
Spanish & $-0.027^{*}$ & -0.009 \\
Control & & \\
Age (Io years) & 0.004 & $0.0337^{*}$ \\
Age squared & $0.00 \mathrm{I}$ & -0.003 \\
Male & $0.025^{* *}$ & $0.016^{* *}$ \\
\hline
\end{tabular}

NOTE: Cells contain regression coefficients. Regressions contain a constant and a set of binary variables for village of residency (not shown). ${ }^{*} p \leq 0.1 ;{ }^{* *} p<0.05 ;{ }^{* * *} p<0.0$ I.

${ }^{a}$ Binary variable. Name of variable $=\mathrm{I}$; excluded category $=$ o.

${ }^{\mathrm{b}}$ Ordinary least squares regression with robust standard errors.

higher scores $(p<$ O.I $)$, and being a man was correlated with $1.6 \%$ more agreement in plant uses.

\section{DISCUSSION AND CONCLUSION}

Three major findings deserve discussion. First, contrary to previous studies, we found that schooling was positively correlated with agreement in knowledge of plant uses. Second, distance from a market town was correlated with higher knowledge, but after about $50 \mathrm{~km}$ agreement in uses of plants declined. This result is not an artifact of the definition used because we found the same result whether we defined knowledge as agreement within or agreement across villages. Third, when villageto-town distance was controlled, other indicators of integration into the market, such as cash earnings and wealth, bore no consistent, significant correlation with knowledge of plant uses.

Why would schooling be correlated with greater agreement in plant knowledge, and why might the relation between knowledge of plant uses and village-to-town distance be inverted-U-shaped? Answer to the two questions are probably linked. Schooling is correlated with greater agreement because students in schools are exposed to similar knowledge about plants and because they have the opportunity to interact with each other. Since schooling has not yet reached the most isolated

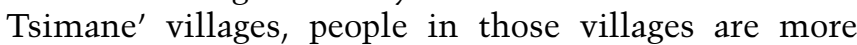
likely to disagree with the group because they have not yet been exposed to the same corpus of knowledge and have had fewer opportunities to interact. The content of the knowledge transmitted in schools could be different from folk knowledge or it could be the same (we cannot tell from the data), but if this explanation is correct the findings point to the potential of using the schooling experience to spread folk knowledge. 
A possible explanation for the weak correlation be tween market-related activities and folk knowledge is that not all those activities exert the same effect on knowledge. For example, it may be that activities that decrease dependency on the forest, such as wage labor. are correlated with less knowledge of plant uses but activities that increase dependency on the forest, such as the sale of forest products, are correlated with more knowledge of plants. Another reason for the lack of visible effect relates to classical measurement errors of the variables that serve as proxies for market participation. Earnings are notoriously difficult to estimate (Deaton I 997). Future studies on the effects of markets on folkknowledge should address diversity in economic activities and try to identify suitable instrumental variables for indicators of integration into the market.

\section{References Cited}

ATRAN, S., AND M. DOUGLAS. I997. "Knowledge and action: Cultural models of nature and resource management in Mesoamerica," in Environment, ethics, and behavior. Edited by M. Bazerman, D. Messick, A. Tinbrunsel, and K. WaydeBenzoni, pp. I7I-208. San Francisco: New Lexington Press.

Benz, B., J. Cevallos, f. Santana, J. Rosales, AND S. GRAF. 2000. Losing knowledge about plant use in the Sierra de Manantlán Biosphere Reserve, Mexico. Economic Botany 54:I83-9I.

BERKES，F.， J . COLDING，AND C. FOLKe. 2000. Rediscovery of traditional ecological knowledge as adaptive management. Ecological Applications I0: 25 I-62.

B E R L I N, B. I992. Ethnobotanical classification: Principles of categorization of plants and animals in traditional societies. Princeton: Princeton University Press.

в OSTER, I. I986. Exchange of varieties and information between Aguaruna manioc cultivators. American Anthropologist $88: 429-36$.

BOSTER, J., AND J. JOHANSON. I989. Form or function: A comparison of expert and novice judgments of similarity among fish. American Anthropologist 91:866-89.

CANIAGO, I., AND S. SiEBERT. I998. Medicinal plant economy, knowledge, and conservation in Kalimantan, Indonesia. Economic Botany 52:229-50.

CONKLIN, H. C. I954. An ethnoecological approach to shifting agriculture. Transactions of the New York Academy of Sciences $17: 133-42$.

DEATON, ANGUS. I997. The analysis of household surveys: Microeconomic analysis for development policy. Baltimore: Johns Hopkins University Press.

G A R R O L. I986. Intracultural variation in folk medicinal knowledge: A comparison between groups. American Anthropologist 88:35 I-70.

GODOY, R. 200I. Indians, markets, and rainforest: Theory, methods, analysis. New York: Columbia University Press.

GODOY, R., N. BROKAW, D. WILKIE, D. COLÓN, A. PALERMO, S. LYE, AND S.WEI. I998. On trade and cognition: Markets and the loss of folk knowledge among the Tawahka Indians. Journal of Anthropological Research 54:2 I9-33.

LOCAY, L. I989. From hunting and gathering to agriculture. Economic Development and Cultural Change 37:737-56.

MAFFI, L. 200I. On biocultural diversity: Linking language, knowledge, and the environment. Washington, D.C.: Smithsonian Institution Press.

REYeS-GARCíA, V., E. BYRON, R. GODOY, V. VADEZ, L. APAZA, E. péreZ, W. LEONARD, AND D. WilKie. 2004. Measuring culture as shared knowledge: Do data collection formats matters? Field Method 16:135-56.
REYeS-GARCía, V., R. GODOY, V. VADEZ, L. APAZA, E. BYRON, E. PÉREZ, W. LEONARD, AND D. WILKIE. 2003. Is ethnobotanical knowledge held communally? Evidence from Bolivian Amerindians. Science 299:1707.

ROMNEY, A., S, WELLER, AND W. BATCHELDER, I986. Culture as consensus: A theory of culture and informant accuracy. American Anthropologist 88:313-38.

SILLIT OE, P. I998. The development of indigenous knowledge. CURRENT ANTHROPOLOGY 39:223-52.

STERNBERG, R., C. NOKES, P. GEISSLER, R. PRINCE，F. OKATCHA, D. BUNDY, AND E. GRIGORENKO. 2OOI.

The relationship between academic and practical intelligence: A case study in Kenya. Intelligence 29:40 I-I8.

VADEZ, V., V. REYES-GARCÍA, R. GODOY, E. BYRON, L. APAZA, W. LEONARD, E. PÉREZ, AND D. WILKIE. 2004. Does integration to the market threaten agricultural diversity? Panel and cross-sectional evidence from a horticultural-foraging society in the Bolivian Amazon. Human Ecology 32:635-46.

ZARGER, R., AND J. R. STEPP. 2004. Persistence of botanical knowledge among Tzeltal Maya children. CURRENT ANTHROPOLOGY 45:4I3-I8.

ZENT, S. 200I. "Acculturation and ethnobotanical knowledge loss among the Piaroa of Venezuela," in On biocultural diver-

$\rightarrow \quad$ sity: Linking language, knowledge, and the environment. Edited by L. Maffi, pp. I90-2I I. Washington, D.C: Smithsonian Institution Press.

\section{The Phenomenology of Perspectivism: Aesthetics, Sound, and Power in Women's Songs from Amazonian Ecuador ${ }^{1}$}

\author{
MICHAEL A. UZENDOSKI, MARK \\ HERTICA, AND EDITH CALAPUCHA TAPUY \\ Department of Anthropology, Florida State University, \\ Tallahassee, FL 32303,U.S.A. (muzendos@mailer.fsu. \\ edu). 2 I I 05
}

[Supplementary material appears in the electronic edition of this issue on the journal's web page (http://www.journals.uchicago. edu/CA/home.html).]

Recent work in Amazonia, such as Descola's (I992, I996a) rehabilitation of the concept of animism, has

(C) 2005 by The Wenner-Gren Foundation for Anthropological Research. All rights reserved oO I I-3204/2005/4604-0008 \$10.00

I. This article is dedicated to the memory of Vicente Calapucha and Serafina Shiguango, the musicians featured in this piece. The following organizations have supported our collective effort: the Fulbright Institute for International Education, the Pew Charitable Trusts, the University of Virginia, Florida State University, the Arizona State University Field School of the Amazon and the Andes, the Dirección Bilingüe Intercultural de Napo, and the Facultad Latinoamericano de Ciencias Sociales of Ecuador. We are grateful to all of them. We thank Syed Ali, Simon Bickler, William Parkinson, Mary Pohl, Joseph Hellweg, Cheryl Ward, Kathryn Josserrand, Nick Hopkins, and Clarene Gravlee for comments on the text and Timoteo Tapuy for his collaboration. 
demonstrated that its societies are characterized by distinctive symbolic patterns of interaction between people and nature. Viveiros de Castro (I998), for example, has shown that Amazonian peoples view nature not as ontologically separate from the human realm but as part of a larger domain of human sociality and experience. Furthermore, he emphasizes the role of bodily intersubjectivity within animism, a cosmological reality that he describes as "perspectivism" (see also Århem I 993). The emphasis in perspectivism is on the body's capacity for transformation, but it also involves the idea that all living things possess souls and that souls circulate in an animistic way (Descola 1992, I996a; Vilaça 2002). The strength of perspectivism is that it focuses attention on the complex subjectivities embedded in Native Amazonian notions of corporeal process and their relations to kinship and cosmology. Here the world is perceived from a distinctive bodily point of view $^{2}$ - the idea of one soul (and one kind of culture) but many bodies, many natures. As Vilaça (2002:35I) explains, "What enables the permutability of the body is precisely the equivalence of spirits: all are equally human, equally subjects. By modifying the body alimentation, change in habits, and the establishment of social relations with other subjects, another point of view is acquired: the world is now seen in the same way as the new companions, that is, the members of the other species." These ideas go beyond cosmology to include social processes. The bodies of spirits, humans, and animals are all changing over time, and in the process these beings take on new subjectivities and relational points of view-transformations that are central to Amazonian ideas and practices of kinship and sociality (Vilaça 2002, Fausto 2000, Overing and Passes 2000, Viveiros de Castro 200I). Indeed, the soul is the inner perspective of the body, a "potency, related to the capacity to produce another body" (Vilaça 2002:364). As all of this work has shown, in Amazonia there is no such thing as a body in stasis; it must constantly be made and remade.

In this report we explore how the poetic structures of grammar and music in three women's songs from the Napo Runa of Amazonian Ecuador evoke the native theory of the body's potency and its ability to attract desirable things, powers, qualities, and people. In confronting the aesthetic and cultural complexity of these songs we have drawn on a variety of theoretical approaches, among

2. These principles point to the core principle of perspectivism, that the body is "a mere envelope (a 'clothing') which conceals an internal human form, usually one only visible to the eyes of the particular species or to certain types of trans-specific beings such as shamans" (Viveiros de Castro I 998:2). All living beings contain the same inner core of soul or soul substance but differ in outer form. Shamans, beings who can travel in time and space, can and do change their outer form, as do animals and spirits. "Body and soul," writes Viveiros de Castro (p. 48I), "just like nature and culture, do not correspond to substantives, self-subsistent entities or ontological provinces, but rather to pronouns or phenomenological perspectives." Indeed, the action and experience of bodily refashioning - the phenomenological side of perspectivist realities-cannot be separated from cosmology, symbolism, aesthetics, and vocal art. them French and Brazilian structuralism (Descola I992, I996a, $b$; Taylor 1993, I996; Vivieros de Castro I998, 200I; Vilaça 2002; Fausto 2000), embodiment (Csordas I990, Merleau-Ponty I962), mimesis (Taussig I993), ethnopoetics (Hymes 2003), and ethnomusicology (Feld I982, Olsen 1996, Seeger I987). Our primary objective is to translate these songs and identify their main aesthetic features, but we also seek to convey something of their meanings as phenomenological acts. We will show that the aesthetic features of these songs resonate powerfully with the mythological and metaphysical qualities of a bird that is at the core of Napo Runa mythology and weave people, their bodies, and those of nonhuman entities together in deeply meaningful ways. The songs speak to the theme of soul potency and the body's refashioning not just in relationship to birds but also in relationship to gender, kinship, and history. They demonstrate the transformative role of music in the fabrication and experience of the body as a locus of power.

\section{THE CONTEXT}

All forms of music among the Napo Runa are termed takina, and people say that all takina originate from samai (soul-substance or breath). Songs are action-powerful music that attracts energy, qualities, people, and power and, if used for the purposes of shamanistic sorcery (sagrana, brujuna), can make others ill. The three songs we examine here come from a copy of a tape recorded in the I980s by the family of Edith Calapucha, which features the music of Edith's grandfather (Vicente Calapucha) and grandmother (Serafina Shiguango), the founders of the native community of Sapo Rumi. Vicente plays the violin and Serafina sings. [Transcripts, translations, and audio files of these songs may be found in the electronic edition of this issue on the journal's web page.] Traditionally, women sing while the men play instruments, although shamans sing specialized songs often glossed as yachai (power/knowledge). The violin was borrowed from the Europeans but modified and played in a distinctly Amazonian style (see Oberem I980:308). Violins are also sometimes used in shamanic practice. The gender distinctions of musical practice reflect the principle of masculine and feminine complementary, a core idea of Napo Runa socioculture (Uzendoski 2004 b).

We argue that these women's songs are a form of shamanic practice, the singer experiencing her body as a special locus of subjectivity as defined by relations with birds and other alters. When women sing they report feeling the power (ushai) of the birds or animals they sing about "in their flesh" (paigunác aichai). The Runa view takina as ushai and believe that shamanic takina allow people to embody power by mimetic association with powerful alters. Singing elicits and reflects the power (ushai) of the singer, a sinzhi warmi (strong woman).

Vicente and Serafina were well known for their musical powers. They used to make their music daily during their morning wayusa tea-drinking ritual, and their affinity for music was a sign of their status as powerful 
beings. Today the reproduction of their music on tape is viewed as a manifestation of their power and samai, which have been passed on to their descendents. Recorded music is highly valued because it furthers indigenous self-determination and historical consciousness, a different kind of mimesis linked to ethnic resurgence (see Whitten and Whitten I988, Uzendoski n.d.). The performance of women's songs is not as prevalent as it once was, and, because of their themes of attraction and seduction it is often difficult to find women who are willing to share their songs with researchers. To make one's songs public, for example, is to enter into a social context in which one's samai and shamanic power become visible to others. In the dangerous world of Amazonian cosmological relations of predator and prey, shamanic actions often elicit counterresponses from rival shamans or spirits (Whitehead and Wright 2004); women's songs are part of this field of relations, thought to influence life, death, sickness, and health.

Not all women's songs are performed in secret, however. As in the past, women still perform them in public during fiestas and weddings. Because the intent is to "make people happy," these songs are not dangerous, but they continue to be regarded as expressions of samai and power. Their intimate connection with emotional states (Harrison I988:147) resonates with the notion that they embody powers of attraction and have influence over the samai of others. They evoke memories of the ancestors who sang these songs before them and the emotions linked to them, and the singers of them are the most respected women in Napo Runa society.

Young people are beginning to relearn the songs of their grandparents and great-grandparents, and men are beginning to perform women's songs, arguing that men among the Shuar and Achuar sing and there is no reason they should not (see Descola I996b, Karsten I998 [I920-2 I]). Women continue to compose new songs that relate to their intimate experiences and visions of the contemporary world. These songs may never be studied by scholars, as they are expressions of shamanistic action aimed at controversial problems (for example, a woman may be seeking to attract a man who is someone else's husband or may be trying to win her husband back from another woman). Some of the most meaningful and powerful women's songs must therefore remain secret. Because of their complexity and their private, emotional, and esoteric nature, they are difficult to study (Harrison I988).

The songs we examine emphasize the power of verbal art and music to transform the body. In these songs women experience the world from various corporeal perspectives defined by rhetorical forms of mimetic transformation. The embodied states here are enacted and experienced as alternative somatic perspectives of the human condition, a point reinforced by the affinities of bird sounds to the musical features of the songs (see Feld I982).
THE METAPHYSICS OF POWER AND SEXUALITY

Harrison's (1988) groundbreaking work on the connections among the body, power, spirit, and music in women's songs from Napo has revealed that gender and sexuality are central to their shamanistic qualities. Singers use their songs to acquire power and seduce men. Attraction, more than just a feminine preoccupation, is one of the defining characteristics of shamanistic action and is the cornerstone of animal-human relations, central to hunting and to masculine agency as well (Uzendoski 2004b). Michael Brown (I985) has discussed the importance of attraction in Aguaruna magic and in hunting and singing and points out that attraction is a property of powerful plant substances as well (pp. 88-90). In Napo it is often said that the anaconda attracts its victims "like a magnet," Anacondas also appear as beautiful men and women (attracting humans of the opposite sex). Male anacondas are said to impregnate women in their dreams by appearing as handsome men (Harrison I988: I62). Just as animals seduce humans, humans can use the ushai of animals and/or plants to seduce other humans. Two plants, simayuka and puma yuyu, confer powers of attraction, and the former is renowned as love magic.

Among the Napo Runa, the complementarity of gender and gendered sexual energy mediates most animal-human relations. Some women have male spirit/animal lovers from whom they acquire special energy and power. More commonly, however, men have female spirit/animal lovers who help them to attract and control women and the animals and fish that they seek. Women's songs connect the singers with the spiritual power of birds, turning them into predators who "hunt" men. In Napo Runa culture, men do not simply "dominate" women. Men and women see themselves as equally powerful and indispensable. Napo Runa women's songs help us to understand something of how their singers experience power and demonstrate the centrality of aesthetic performance to perspectivist cosmologies. In Armstrong's (I98I) terms, they have an affecting presence.

\section{ANALYSIS OF THE SONGS}

The texts of the three songs presented here consist of ordered sets of lines that can be considered as representing scenes, stanzas, and verses (see Hymes 2003:303). As in myth narratives, the predominant poetic features of Napo Runa music are couplets, repetition, grammatical parallelism, syllabic patterning, and rhetorical initial words and ending words (Uzendoski I 999). High-pitched singing marks couplets and indicates the beginning of a line or verse. It imitates birdsong and helps to convey the transformation into a bird and the upward motion of flight. Drawn-out vowels form a complementary opposite to the high-pitched tones. Found at the ends of verses, they have a descending quality and signal closure or outcome, a transition to silence or pause. These features create what Hymes (2003:304-5) has termed "suc- 
cession," the equivalence of form that gives shape to action (see also Nuckolls 2000, Jakobson 2000 [I960]).

The succession here is something like an aesthetic form for the elicitation of ushai. Opposites often come together to form a third entity that transcends them (Uzendoski I999). Taussig (I993:I06), speaking of the Kuna chanter, says that he "chants himself into the scene. He exists not just as a subject but also a mimeticised Other. ... He creates the bridge between original and copy that brings a new force, the third force of magical power, to intervene in the human world." Similarly, the singer in these songs sings herself into a person of power and embodies this power in her performance. In so doing, she intervenes in the world both as a shamanic actor and as a sinzhi warmi (cf. Whitten and Whitten I988).

The first song, "Birds and Flowers," features a woman turning into various kinds of birds, visiting flowers, flying through the sky, and calling on her husband to wait for her. The birds it mentions are the siccha, the kindi (a hummingbird), the suyu (a bird that flies in flocks high in the skyl, and the duck. The song has four scenes that correspond to a transformation from one bird form to the next. Each scene is made up of two or three stanzas. Its main poetic features are repetition, couplets, parallelism, imagery, and rhythm, and its main theme is transformation into birds. While singing, the woman takes on the subject position of four different birds and visits flowers that provide her with nectar. She ascends and descends, moving between the heavens and the earth, and as a duck visits water and the snow-covered mountains. She refers to herself as special kinds of womansiccha warmi (siccha-woman), kindi warmi (hummingbird-woman), suyuguna warmi (suyu birds-woman), heaven-women, and woman-like duck. The use of these constructions (commonly employed to denote humananimal transformations in Quichua) and the constant use of the first person express the embodiment of the birds' perspectives by the performer-a transformation that is mimetically experienced by the singer.

The main musical feature is a high-pitched, ascending voice that evokes the rapid motion of the hummingbird darting from flower to flower as it feeds. By creating a detailed image of the bird-woman, the singer shamanistically taps into the perceived power of these beautiful creatures; her body becomes what she sings. A poetic and ontological "equivalence" (Jakobson 2000 [1960]) is established between humans and birds; like birds, the songs travel far and wide to reach the souls of their targets.

Scenes are marked by transformations into different kinds of birds. Stanzas begin with high-pitched tones and end with softer, low-pitched and drawn-out vowels, which in turn fade into pauses. Verses are often coupled, the second repeating the previous one with a slight variation in syntax, tone, or length. The phrase shayauni ("I am standing") often signals the end of stanza. "Standing" here is a kind of power image with connotations of strength and resilience (Harrison 1988). Almost every line ends in $a$ or $i$, usually drawn out to produce the vocal effect of descent. In certain words that end in -in, such as wamburin, the $n$ is barely audible, mimicking the bird's descent. Lines tend to end with three-syllable words, and these micro-relations of three may resonate with the idea of an intervening relation created through twinning or the transformation of opposites by a third entity, which is power.

The second song, "Huallaga," is an example of Hill's (I995:xi) assertion that "music and history are closely intertwined throughout lowland South America" (see also Whitehead 2003). The Huallaga is a river in Peru to which the Napo Runa used to travel, first with the Jesuits and later by themselves to obtain salt (Reeve I993, Muratorio I99I). ${ }^{3}$ The singer was a member of the last generation of Napo Runa to have traveled to the Huallaga. Her song shows the complementary nature of upriver and downriver ecological zones in the indigenous view. She sings to her husband, asking him to take her with him on the long, arduous journey.

This song presents a marked contrast with the first one. The pattern here is four rather than three syllables in each line. The structure of verses also follows this pattern, with generally two-line couplets making up a verse. The first line is sung in the high pitch while the second is lower-pitched. The phrase here, "Rigra, rigra" (Arming, arming), provides the central image, conveying the body movement involved in poling a canoe upriver. Because in Quichua rigra means "wing" as well as "arm," this phrase could also be translated as "winging, winging." This interpretation is reinforced by the singer's reference to a bird (tayuyulla) in the following lines.

One of the defining characteristics of birds is that they are masters of movement and travel, and this is also a notion associated with shamanic power in the Upper Amazon. As Descola (1996b:323) has noted, Achuar shamans employ rhetorical structures in their songs that are "a reaffirmation of the shaman's membership to a vaster community ... even if he has not traveled much physically, a shaman is by nature a cosmopolitan creature." Indeed, these songs show that ushai is linked to movement and transformation, implicit characteristics of the power of birds and other shamanic beings. ${ }^{4}$

"Fish," according to the singer, was formerly sung during drinking parties among auya, relatives linked by the marriage of their children. In it the in-laws try to make the woman drunk, and she likens her ability to resist drunkenness to a chinlus fish's ability to resist poison (barbasco). The chinlus is a small fish that is unique to the fast-moving currents of the Upper Napo region. While it is sometimes caught with a net or a hook, it has an extraordinary ability to move quickly in rapids

3. These trips ceased with the border war with Peru in I94I, which closed off trade from the Upper Napo region downriver toward Amazonia. Trade upriver (into the Andes) and downriver has been a feature of this area for quite some time and can also be shown to be central to pre-Hispanic dynamics (Uzendoski 2004a).

4. Because Quichua-speakers do not separate time from space, this theme of traveling evokes temporal as well as spatial movement. powerful beings are able to move through different pacha or worlds of space-time (see Whitten and Whitten I988). 
and resist barbasco. The song calls upon the power of the chinlus, elicited through mimesis of the fish's movements, to make the woman strong. It makes reference to the time when Runa used to work gathering gold, and it also locates the singer within the landscape of her home with references to the Sapo Rumi petroglyph and the Yanayacu River. It also defines the singer in terms of her kinship identities: she is among auya, and her name, Shiguango, identifies her as a woman of a particular ayllu (kinship group). The song thus combines the animal and historical perspectives of the first two songs with identities of kinship.

Like the first song, this one shows a preference for three-syllable ending words. Again, beginning phrases are sung at high pitch. In contrast to the previous two songs, this one has longer verses-many lines strung together and sung in a more rapid and low-pitched voice. One theme of these repetitions is the assertion of various identities of the singer: "Siren," "money-mother," "Sapo Rumi woman," "gold woman," "Yanayacu woman," "Shiguango woman," and eventually "chinlus woman." The historical identities, like the animal alters, are implicitly linked to the singer's power.

One of the central images of this song is the use of the sound-symbolic (Nuckolls I996, 2000) term cuscalla, which indicates standing firm within a current or against a powerful resistant force, to describe the fish woman as resisting her in-laws' efforts to make her drunk. She is also said to be "escaping like the wind" in the current, a construction that draws a figurative connection between the movement of the fish and that of birds and highlights the fish's ability to move with currents that carry it to safety. Thus, like the bird, the fish is likened to a master of movement that is intelligent, agile, and powerful.

Vilaça (2002:349) has shown that transformations of kinship and identity and relationships with animals are both structured by the implicit principles of perspectivism in that "humanity is conceived of as a position, essentially transitory, which is continuously produced out of a wide universe of subjectivities that includes animals." The above songs define the singer's soul potency through multiple identities (acquired over time) linked to animal subjectivity, kinship, and historical experiences and through the features (rivers and the Sapo Rumi petroglyph) and history of her place of residence.

\section{THE HUMANITY OF BIRDS}

These three women's songs feature mimetic transformation as a central image. Their rhetorical patterning is applied not only to nature but also to kinship, residence, and history. Birds are the core theme; in two of the songs the singer becomes various birds, and in the third she becomes a chinlus, which, like a bird, is associated with movement and flight. This centrality of birds as objects of metaphor, power, and mimesis is found in other sources that deal with Amazonian Ecuador (Whitten 1976, I985; Whitten and Whitten 1988; Karsten I998). Whitten (I976:44). proposes that birds are associated with mastery of vertical space and travel and carry women's songs (and their sexualized power to influence others) to faraway places. The implication here is that the songs are transformations of birds-that birds take on the samai of the singers.

This idea of birds and women's combining corporeal essences becomes even clearer when one looks at Napo Runa myths, whose culture heroes are the twins Cuillurguna (Orr and Hudleson I971:2-6). The mother of the twins is the ilucu (the common potoo [Nyctibius griseus, Nyctibiidae), a bird that sings at night during a full moon. As the story goes, Ilucu has been impregnated by her brother, who upon being discovered ascends into the sky and tries to take her with him by making a ladder of arrows. She falls off the ladder, however, and they become separated. The brother then solicits the help of ilucu birds to help her ascend, but they cannot fly high enough. He then turns into the moon, and she becomes an ilucu. Every time the moon comes out, it is said, one can hear Ilucu calling out to her lover, "luuu, luuu, luuu, luuu," a sound-symbolic representation of the bird's call that is explicitly associated with feminine ritual wailing (Orr and Hudleson I97I:4) and the qualities of women's songs.

This myth is a microcosm of the complex relations surrounding women's songs. Ilucu, the conceptual "mother" of the Napo Runa, also represents the embodied coalescence of birds, femininity, sexuality, and song. Her song, like the songs of contemporary women, expresses feelings of love and sadness (both translated as llakina) caused by distant men. It also highlights the power of attraction, for she and the moon are separated but linked by a powerful mutual desire. These meanings are not merely esoteric. It is common for people to refer to sad or lonely women as "Ilucu," linking her to the destiny and powers of the mythological figure herself. The sounds of the common potoo are central to women's vocal art. This is the ecological palette of Napo Runa mythological aesthetics, at least of its feminine side.

The ilucu's call resonates with the verse structure, melodic contour, tone, and pauses of women's voices. Like women's songs, it is structured by lines and verses. The call usually has three "lines" but sometimes four or even five and is then repeated, but with variation that makes it both patterned and random, a feature of women's sons. Furthermore, what ethnomusicologists would call the melodic contours of women's and ilucu songs are strikingly similar, as the general motion of both songs is downward. As the ilucu's song descends, the volume of the sound drops. This "tone painting" resonates with the poetic movements of birds as agents of vertical movement. The rendering of the tones in the women's songs and the ilucu's call are also similar in the way individual tones are approached, held, and left. Especially in its opening tone, the ilucu does not hit a note precisely and hold that pitch; instead it initiates the tone and then slides up very slightly as in what vocalists refer to as "scooping." The tone then wavers slightly, exhibiting very slight and subtle changes of frequency. This same wavering of pitch is also clearly heard in the 
women's songs, especially in the upper register of the singer's voice. Another dramatic feature of similarity is the intervalic skipping (skipping one interval in a range) that we found both in all but one of the ilucu calls we heard and in the women's songs-a detail that we hope can be explored further in future research.

This similarity of patterning between bird calls and song shows the usefulness of ethnopoetic and ethnomusicological analysis in anthropological research-especially among Amazonian peoples that define sociality in terms of complex aesthetic forms and practices (Overing and Passes 2000:8). Our findings resonate with those of a groundbreaking study by Feld (I982), who draws on the work of Robert Armstrong (I98I) in showing that in the theory of music of the Kaluli of Papua New Guinea "becoming a bird" is the core aesthetic metaphor. The sounds of nature are also the sounds of humanity, and vocal art evokes an affective presence of mythological truths that are located in somatic transformations (birth and death). Feld's insights highlight the intimate relationship between vocal art, myth, presence, and the sounds of nature. Future research may explore in more detail the similarities and differences between Amazonian and Melanesian verbal art/music (see Knauft 1997, Gregor and Tuzin 200I).

\section{CONCLUSIONS}

In this study we have experienced something of the aesthetics of three women's songs from the Napo Runa of Ecuador. These three songs employ complex principles of music and sound that, in the native view, mimetically create relations of attraction and embodiment with natural beings. They combine the experience of human-animal relations, corporeal essences, gender, history, and subjectivities and highlight an often hidden aspect of shamanistic and cosmological action-feminine attraction. Taylor (I993, I 996) and Surrallés (2003) have shown the centrality of the senses to meaningmaking and social action in Amazonia. Additional insights can, as we have seen, be gleaned from the study of the way sound allows people to experience the somatic states and aesthetic contours of their perspectivist worlds ${ }^{5}$ and of the role of gender-the symbolic and social issues associated with the female body-in the experience of perspectivism. Much work remains to be done in detailing the ways in which people experience their bodies as intersubjective entities. We hope that, in showing that, for people in Napo, historical, regional, and kinship identities are also woven into these complex relationships, we have succeeded in morphing Viveiros de Castro's rich set of ideas into another "bodily state," thus demonstrating the potency of its spirit and

5. Surrallés (2003:786), for example, in analyzing Candoshi greeting ceremonies, has noted that "vision is ... the expression of presence" and making eye contact with others is "a sign of challenge and seduction," but these greeting ceremonies are defined more by music than by words. For an account of the role of sound in an Amazonian society, see Graham (I995). encouraging others to experience the transformation from their own ethnographic perspectives.

\section{References Cited}

Å R H M M K А J . I993. "Ecosofia makuna," in La selva humanizada: Ecología alternativa en el trópico húmedo colombiano. Edited by F. Correa. Bogotá: Instituto Colombiano de Antropología/Fondo FEN/Colombia Fondo Editorial CEREC.

ARMSTRONG, ROBERT PLANT. I98I. The powers of presence: Consciousness, myth, and affecting presence. Philadelphia: University of Pennsylvania Press.

B ROWN, MICHAEL. I985. Tsewa's gift: Magic and meaning in an Amazonian society. Washington, D.C.: Smithsonian Institution Press.

CSORDAS, THOMAS J. I990. Embodiment as a paradigm for anthropology. Ethos I 8(1):5-47.

DESCOLA， PHILIPPE. I992. "Societies in nature and the nature of society," in Conceptualizing society. Edited by Adam Kuper, pp. I07-26. London and New York: Routledge.

- I996a. "Constructing nature: Symbolic ecology and social practice," in Nature and society: Anthropological perspectives. Edited by Philippe Descola and Gisli Pálsson, pp. 82-IO2. London: Routledge.

1996b. The spears of twilight: Life and death in the Amazon jungle. Translated by Janet Lloyd. New York: New Press.

FAUSTO, CARLOS. 2000. Of enemies and pets: Warfare and shamanism in Amazonia. American Ethnologist 26:933-56.

FELD, STEVEN. I982. Sound and sentiment: Birds, weeping, poetics, and song in Kaluli expression. Philadelphia: University of Pennsylvania Press.

GR A H A M, L A U RA. 1995. Performing dreams: Discourses of immortality among the Xavante of Central Brazil. Austin: University of Texas Press.

GRegor, ThOMAS A., AND DOnAld tuZin. 200I. Gender in Amazonia and Melanesia: An exploration of the comparative method. Berkeley: University of California Press.

HARRISON, REGINA. I988. Signs, songs, and memory in the Andes: Translating Quechua language and culture. Austin: University of Texas Press.

HILL, JONATHAN. I995. "Foreword," in The land without evil: Tupí Guaraní prophetism, by Hélène Clastres. Urbana: University of Illinois Press.

HYMES, DELL. 2003. Now I know only so far: Essays in ethnopoetics. Lincoln: University of Nebraska Press.

JAKOBSON, ROMAN. 2000 (I960). "Linguistics and poetics," in The Routledge language and cultural theory reader. Edited by Lucy Burke, Tony Crowley, and Alan Girvin, pp. 334-40. New York: Routledge.

K A R S TEN, RAFAEL. I 998 (I920-2I). Entre los Indios de las selvas del Ecuador. Quito: Abya-Yala.

KNAUFT, BRUCE. I997. Gender identity, political economy, and modernity in Melanesia and Amazonia. Journal of the Royal Anthropological Institute, n.s., 3:233-59.

MERLEAU-PONTY, MAURICE. I962. Phenomenology of perception. Translated by Colin Smith. London: Routledge.

MURATORIO, BLANCA. I99I. The life and times of Grandfather Alonso: Culture and history in the Upper Amazon. New Brunswick: Rutgers University Press.

N U C K OLl S, JA I S B. 1996. Sounds like life: Sound-symbolic grammar, performance, and cognition in Pastaza Quechua. London: Oxford University Press.

. 2000. "Spoken in the spirit of a gesture," in Translating native Latin American verbal art: Ethnopoetics and ethnography of speaking. Edited by Kay Sammons and Joel Sherzer, pp. 233-5 I. Washington, D.C.: Smithsonian Institution Press.

о B EREM, ud O. I980. Los Quijos: Historia de la transculturación de un grupo indígena en el Oriente ecuatoriano. Otavalo: Instituto Otavaleño de Antropología.

OLSEN, DALE A. I996. Music of the Warao of Venezuela: Song 
people of the rain forest. Gainesville: University Press of Florida.

ORR, CAROLINA, AND JOHN hudLeSON. i97i. Cuillurguna: Cuentos de los Quichua del Oriente ecuatoriano. Quito.

OVERING, JOANNA, AND ALAN PASSES. 2000. "Introduction: Conviviality and the opening up of Amazonian anthropology," in The anthropology of love and anger. Edited by Joanna Overing and Alan Passes, pp. I-30. London: Routledge.

REEVE, MARY ELIZABETH. I993. Regional interaction in the Western Amazon: The early encounter and the Jesuit years, I 538-1767. Ethnohistory 4I:I06-38.

SeEger, Anthony. I987. Why Suyá sing: A musical anthropology of an Amazonian people. Cambridge: Cambridge University Press.

SURRALlÉS, ALEXANDRE. 2003. Face to face: Meaning, feeling, and perception in Amazonian welcoming ceremonies. Journal of the Royal Anthropological Institute, n.s., 9:775-9I.

TAUSSIG, MICHAEL. I993. Mimesis and alterity. New York: Routledge.

TAYLOR, ANNE CHRISTINE. I993. Remembering to forget: Identity, mourning, and memory among the Jivaro. Man 28: $653-78$.

. I996. The soul's body and its states: An Amazonian perspective on the nature of being human. Journal of the Royal Anthropological Institute, n.s., 2:20I-I 5 .

UZENDOSKI, MICHAEL. I999. Twins and becoming jaguars: Verse analysis of a Napo Quichua myth narrative. Anthropological Linguistics 4I:43 I-6I.

- 2004a. The horizontal archipelago: The Quijos-Upper Napo regional system. Ethnohistory 5 I:3 I7-57.

- 2004b. Manioc beer and meat: Value, reproduction, and cosmic substance among the Napo Runa of the Ecuadorian Amazon. Journal of the Royal Anthropological Institute, n.s., I0:883-902.

. n.d. The Napo Runa of Amazonian Ecuador. Urbana: University of Illinois Press. In press.

VILAÇA, APARECIDA. 2002. Making kin out of others in Amazonia. Journal of the Royal Anthropological Institute, n.s., 8:347-65.

viveiros de CAStro, eduardo. I998. Cosmological deixis and Amerindian perspectivism. Journal of the Royal Anthropological Institute, n.s., 4:469-88.

. 200I. "Gut feelings about Amazonia: Potential affinity and the construction of sociality," in Beyond the visible and the material: The Amerindianization of society in the work of Peter Rivière. Edited by Neil L. Whitehead and Laura M. Rival, pp. I9-44. Oxford: Oxford University Press.

WHITEHEAD， NEIL L. 2003. "Introduction," in Histories and historicities in Amazonia. Edited by Neil L. Whitehead, pp. vii-xx. Lincoln: University of Nebraska Press.

WhiteheAd, Neil L., AND ROBIN WRight. 2004. "Introduction: Dark shamanism," in Darkness and secrecy: The anthropology of assault sorcery and witchcraft in Amazonia. Edited by Neil L. Whitehead and Robin Wright, pp. I-19. Durham: Duke University Press.

WhitTen, NORMAN E., JR. I976. Sacha Runa: Ethnicity and adaptation of Ecuadorian jungle Quichua. (With the assistance of Marcelo Naranjo, Marcelo Santi Simbaña, and Dorothea Whitten.) Urbana: University of Illinois Press.

- I985. Sicuanga Runa: The other side of development in Amazonian Ecuador. Urbana: University of Illinois Press.

Whit TEN, NORMAN, E., JR., AND DOROTHEA Whit T E N. I998. From myth to creation. Urbana: University of Illinois Press.

\section{Differential Mortuary Treatment among the Andean Chinchorro Fishers: Social Inequalities or In Situ Regional Cultural Evolution? ${ }^{1}$}

\author{
BERNARDO T. ARRIAZA, MATTHEW \\ DOUBRAVA, VIVIEN G. STANDEN, AND \\ HERBERT HAAS
}

Departamento de Arqueología y Museología, Centro

de Investigaciones del Hombre en el Desierto,

Universidad de Tarapacá, Casilla 6-D, Arica, Chile

(barriaza@uta.cl (Arriaza, Standen)/State University of

New York at Buffalo, School of Medicine and

Biomedical Sciences, Buffalo, NY, U.S.A. (Doubrava)/

RC Consultants, Inc., 2846 Marida Court, Las Vegas,

NV 89I20, U.S.A. (Haas). 8 I 05

[Supplementary material appears in the electronic edition of this issue on the journal's web page (http://www.journals.uchicago. edu/CA/home.html).]

Chinchorro artificial mummification practices, starting at $6000 \mathrm{cal} \mathrm{BC}$ and declining around $2000 \mathrm{cal} \mathrm{BC}$, reveal an intriguing and sophisticated socio-religious milieu for an early Andean preceramic hunter-gatherer fishing society (see, e.g., Allison et al. I984; Arriaza I995a, $b$; Schiappacasse 1994; Standen I99I; Rivera I994; Wise I994) On the basis of the burial patterns, Standen (I99I, I997) has argued that Chinchorro mortuary treatment was selective-that not everyone was mummified and that bodies with different treatment or different styles of mummification (e.g., natural versus artificial) found buried together were in fact contemporaneous. This thought-provoking proposition raises various issues. Does differential mummification reflect a family lineage, or, contrary to our preconceived notions, is it evidence of social hierarchy and inequalities on the Atacama coast during preceramic times? Pointing to the clusters of the existing radiocarbon dates, Arriaza (I994a, $b$, and I995 $a$, $b$ ) has argued, in opposition to Standen's view, that Chinchorro mummification practices were egalitarian regardless of sex or age. He has suggested that the intermingling of different types of mummies within a cemetery and their stylistic variation (e.g., black and red) could be explained by the reuse of space and cultural variation over time rather than synchronic social-hierarchical distinctions. He has argued that the Chinchorro reverence for the dead through mummification was an enduring tra-

(C) 2005 by The Wenner-Gren Foundation for Anthropological Research. All rights reserved oo I I-3204/2005/4604-0009\$ I0.00

I. This research was funded by the National Geographic Society, Grant No 57 I2-96, and the U.S.A.-Chilean Fulbright Commission Fellowship 2002-2003. 
dition along the Atacama coast and therefore changes over time should be expected.

Arriaza $(\mathrm{I} 995 a, b)$ has pointed out that, because artificial mummification requires high energy investment, if the individuals with this complex treatment were members of a higher-ranking group, then they should be the minority while the supposed lower-ranking individuals, whose bodies were desiccated by the sand and heat of the desert (natural mummification), should be the majority. So far this does not appear to be the case (table I). Of 96 Chinchorro mummies exhumed from the Morro I site, for example, $37 \%$ were naturally mummified, while $63 \%$ were human-made in various styles-black, red, and mud-coated. Black mummies had rebuilt skeletal elements with flesh replaced by clay; the bodies were painted with black manganese pigment and had short human-hair wigs (fig.I). Red mummies were eviscerated bodies painted with red ochre and had long human-hair wigs (fig. 2). Mud-coated mummies were bodies encased in mud.

To test the validity of the two hypotheses-social inequalities versus evolutionary cultural changes-we selected I 5 Chinchorro mummies to be radiocarbon-dated. The mummies came from four cemeteries, and those buried together had distinctive mummification styles. Chinchorro cemetery stratigraphy is horizontal rather
TABLE I

Chinchorro Mummies from Arica by Type and

Cemetery

\begin{tabular}{|c|c|c|c|c|c|}
\hline Site & $\begin{array}{l}\text { Black and } \\
\text { Complex }\end{array}$ & Red & Natural & Mud & Total \\
\hline Morro I & 8 & 27 & 36 & 25 & 96 \\
\hline Playa Miller 8 & I & 9 & o & $\mathrm{O}$ & IO \\
\hline Morro I-6 & $\mathrm{O}$ & $\mathrm{O}$ & 69 & $\mathrm{O}$ & 69 \\
\hline Morro I-5 & $\mathrm{O}$ & I7 & I & $\mathrm{O}$ & I 8 \\
\hline Morro Uhle & $\mathrm{O}$ & 9 & I & 2 & I 2 \\
\hline Arica & 2 & 0 & $\mathrm{O}$ & $\mathrm{O}$ & 2 \\
\hline Chinchorro I & 2 & $\mathrm{O}$ & $\mathrm{O}$ & $\mathrm{O}$ & 2 \\
\hline Maestranza I & 7 & $\mathrm{O}$ & 4 & $\mathrm{O}$ & I I \\
\hline Quiani & $\mathrm{O}$ & I & $\mathrm{O}$ & $\mathrm{O}$ & I \\
\hline Maderas Enco I & 3 & $\mathrm{o}$ & $\mathrm{O}$ & $\mathrm{O}$ & 3 \\
\hline Total & 23 & 63 & I I I & 27 & 224 \\
\hline Number Dated & IO & I 3 & I3 & 3 & 39 \\
\hline
\end{tabular}

than vertical. Bodies were interred as a continuum, not as burial mounds. Multiple natural or artificial layers of sediments have not been noted. In addition, all of the bodies were buried superficially (less than a meter deep), and individual tombs are absent. This horizontal burial makes the classic stratigraphic superposition model inapplicable, and therefore context, seriation, and radio-

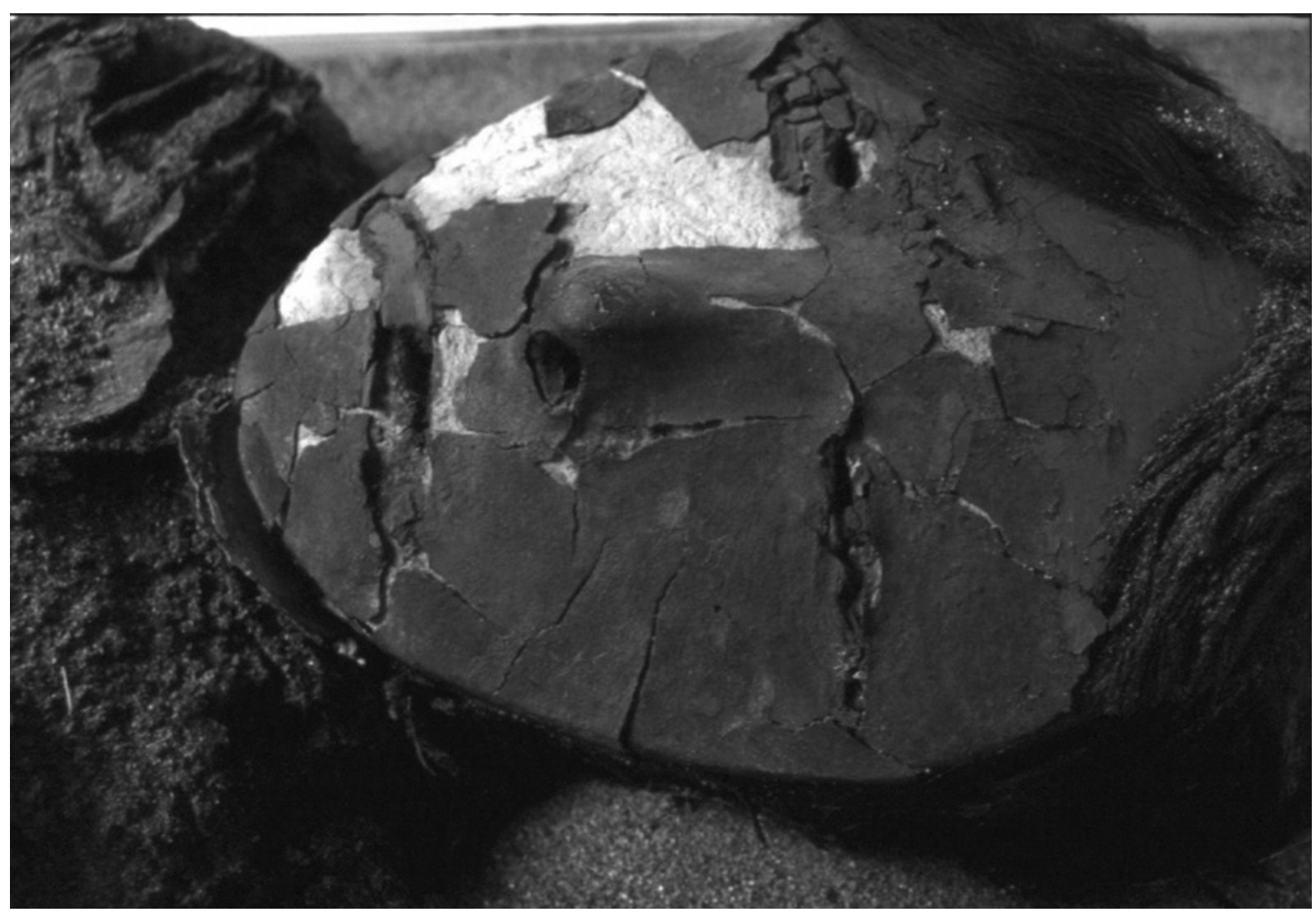

Fig. I. Chinchorro mummy, black style. 


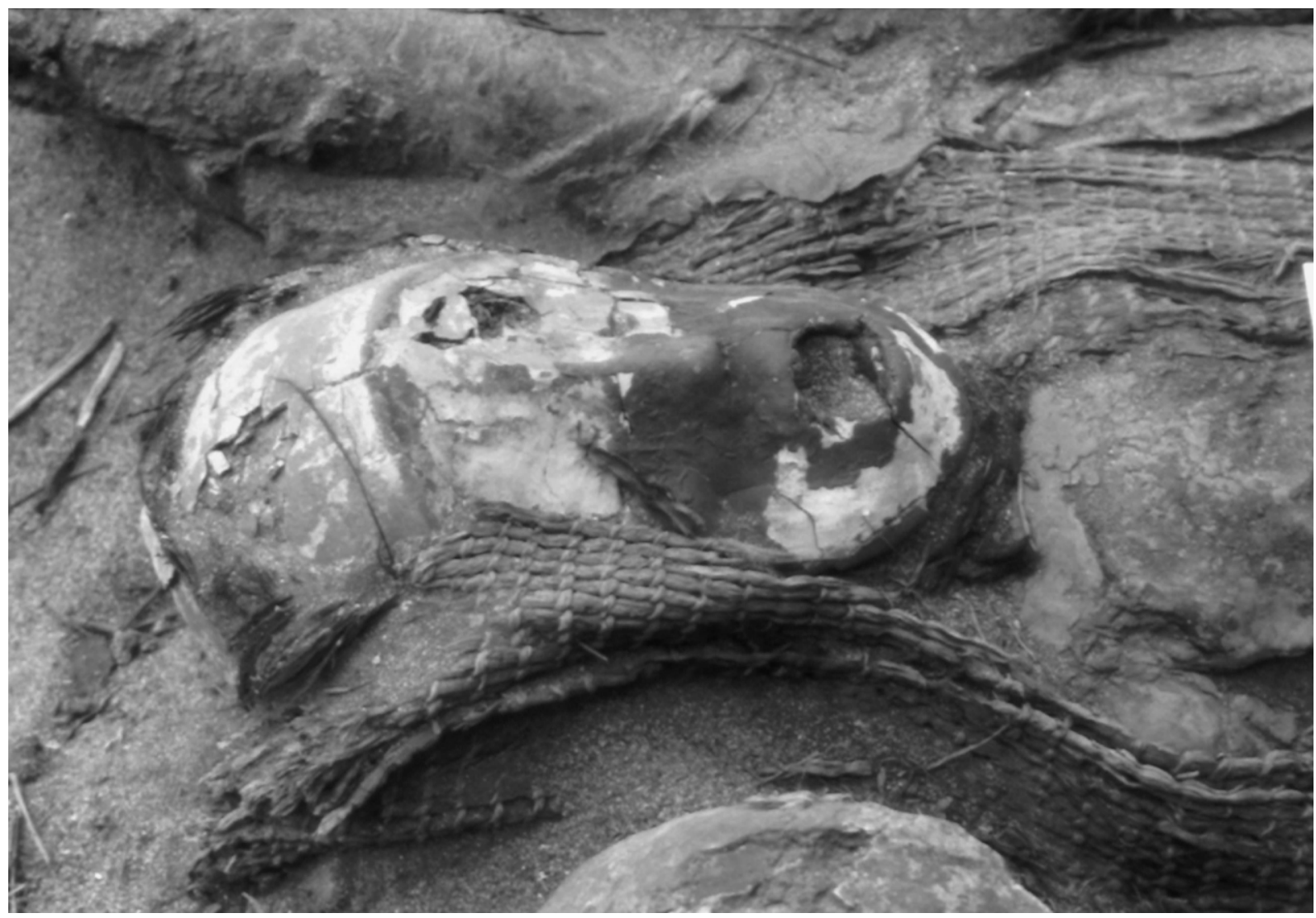

Fig. 2. Chinchorro mummy, red style.

carbon dating of the mummies are crucial for unveiling Chinchorro biocultural evolution.

\section{METHODOLOGY}

Two of us (BTA and VGS) agreed on the selection of I5 mummies that had been found buried in clusters or groups in four cemeteries (Morro Uhle, Morro I, Playa Miller 8, and Maestranza I) (fig. 3). Most of the mummies are currently housed at the Museo Arqueológico San Miguel de Azapa (MASMA) in Arica, Chile. All samples were collected by us and radiocarbon-dated at the Desert Research Institute radiocarbon laboratory, University of Nevada, Las Vegas, under the supervision of two of us (HH and MD [see Doubrava 200I]). The mummies and the materials selected for dating are summarized in table 2. For specimen Morro I TioB two samples were taken from the same mummy.

The following criteria were used for selecting the mummies for sampling:

I. Bodies naturally preserved buried next to bodies with artificial mummification (black or red style or mudcoated). Two sets of mummies from two different cemeteries were available to be sampled for radiocarbon dating to test for contemporaneity. The first set comes from the Morro I site and consists of a mud-coated mummy
(Morro I T23 $\mathrm{C}_{12}$ ) buried next to a naturally mummified body (Morro I $\mathrm{T}_{23} \mathrm{C}_{5}$ ). Two of us (BTA and VGS) excavated these mummies in I983-84. The other set comes from the Maestranza I site, which we excavated in I 997. Here a naturally mummified body (Maestranza I CI) was found lying next to a black mummy (Maestranza I C4). Following Arriaza, we hypothesized that the resulting dates would be diachronic.

2. Bodies with complex mummification techniques (black or red) buried next to bodies with simpler techniques. Two sets of mummies from the Morro I site were tested for contemporaneity. The first set consisted of a red mummy (Morro I $\mathrm{T}_{25} \mathrm{C}_{5}$ ) burried next to a mudcoated mummy that had been eviscerated (Morro I T25 C6), previously dated to $2620 \pm$ IOO BC (uncalibrated) (Arriaza I995 $b$, Standen I99I). The second set corresponds to a partially prepared body (Morro I TiоB) buried near a cluster of black mummies (Morro I TI cluster). The different treatment of Morro ITıоB precluded us from classifying it. We took two samples for radiocarbon dating and hypothesized that the dates for this complex mummy would fall after the black mummies from the Morro I Ti cluster.

3. Cluster of bodies with the same kind of artificial mummification (black or red). Two sets of mummies 
were available to validate existing radiocarbon dates for each style. The antiquity of the complex mummification styles (black and red) was in need of confirmation, since Allison et al. (1984), had dated the red mummy Morro I $\mathrm{T}_{7} \mathrm{C}$ I to $5860 \pm \mathrm{I} 80 \mathrm{OCC}$ (uncalibrated) while Standen (I991:288) had obtained a younger date of $2570 \pm 90 \mathrm{BC}$ (uncalibrated) for the same mummy. We argued that the latter date was correct (Arriaza I995 $a, b$; Standen I997). We selected a group of red mummies from tomb 7 of the Morro I site-Morro I $\mathrm{T}_{7} \mathrm{C}_{4}$, Morro I $\mathrm{T}_{7} \mathrm{C}_{5}$, and Morro I $\mathrm{T}_{7} \mathrm{C} 6$ - for radiocarbon dating. We hypothesized that all the resulting dates for this red cluster would be contemporaneous and cluster around 2000 BC (uncalibrated), validating our argument that these red mummies emerged late.

4. Bodies mummified in similar ways from different sites. On the basis of the availability of mummies, we selected three cemeteries from Arica-Playa Miller 8, Morro I, and Maestranza I. These cemeteries were located about I $\mathrm{km}$ from each other. The first sample (PLM 8 3254) was a black mummy from Playa Miller 8 now housed at the Museo Nacional de Historia Natural in Santiago (Alvarez I 969). The second sample came from our I983-84 excavation of the Morro I site, which produced a cluster of eight black mummies. One of them, Morro I $\mathrm{TIC}_{4}$, was dated to 32 IO $\mathrm{BC} \pm$ I Io (uncalibrated). From this cluster, Morro I $\mathrm{TI}_{\mathrm{I}} \mathrm{C}_{5}$, housed at the Museo Chileno de Arte Precolombino in Santiago, was selected to be tested for contemporanetiy. The third black mummy sample dated was Maestranza $\mathrm{IC}_{4}$. We predicted, on the basis of the similarity of the mummification, that all these black mummies would cluster around 3000 BC (uncalibrated). Finally, four red mummies housed at the MNHN were dated. Max Uhle excavated these mummies, none of which have been previously dated, in the early I 900 s in Arica. The samples

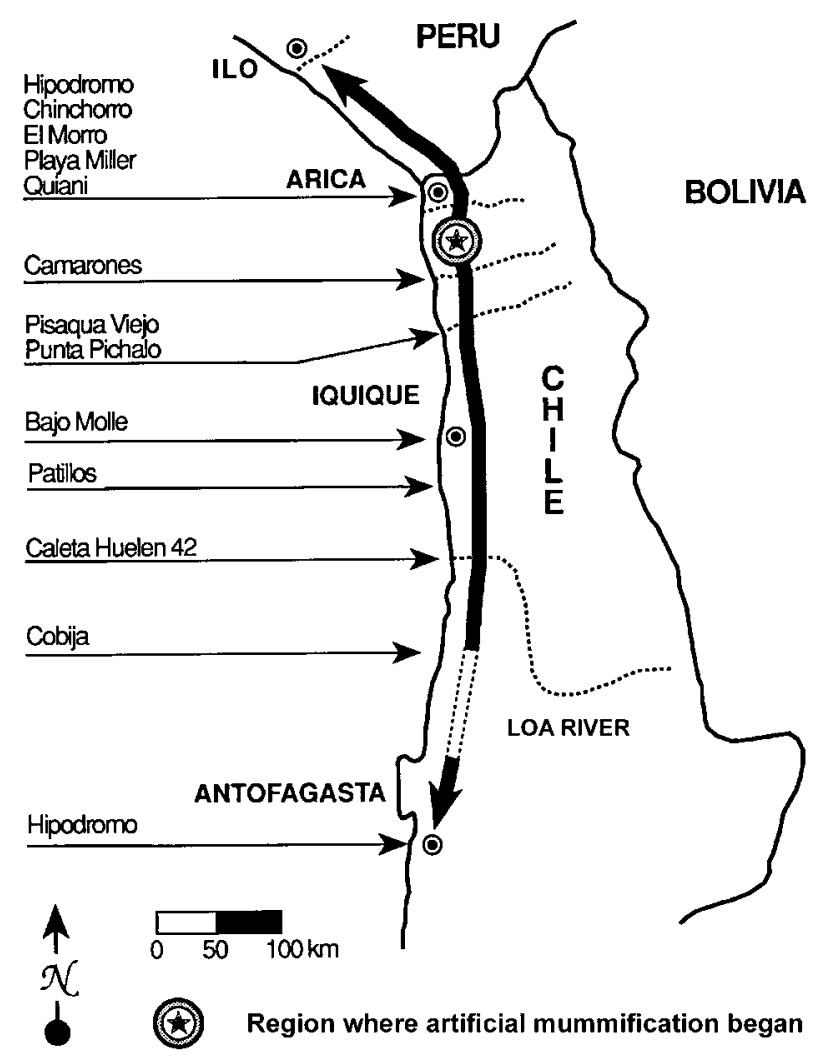

Fig. 3. Chinchorro sites, after Arriaza (1995).

TABLE 2

Newly Dated Mummy Samples

\begin{tabular}{|c|c|c|c|c|c|}
\hline Sample & Style & $\begin{array}{c}\text { Type of } \\
\text { Sample Dated }\end{array}$ & Sex & Biological Age & Museum \\
\hline Morro I $\mathrm{T}_{7} \mathrm{C}_{4}$ & Red & Muscle tissue & $\mathrm{F}$ & Adult & MASMA \\
\hline Morro I T7 55 & Red & Reeds & M & $2-3$ years & MASMA \\
\hline Morro I T7 66 & Red & Wool, hair, and muscle & M & Infant & MASMA \\
\hline Morro $\mathrm{T}_{25} \mathrm{C}_{5}$ & Red & Camelid hair and wool & $\mathrm{F}$ & O-2 months & MASMA \\
\hline Morro I $\mathrm{T}_{23} \mathrm{C}_{12}$ & Mud & Muscle tissue & $\mathrm{F}$ & $20-25$ years & MASMA \\
\hline Morro I $\mathrm{T}_{2} 3 \mathrm{C}_{5}$ & Natural & Muscle tissue & $\mathrm{F}$ & $25-30$ years & MASMA \\
\hline Morro I TioB & Complex & Vegetable material & $\mathrm{F}$ & Adult & MASMA \\
\hline Morro I TiоB & Complex & Bone & $\mathrm{F}$ & Adult & MASMA \\
\hline Maestranza I $C_{I}$ & Natural & Bone & M & I4-I 5 years & MASMA \\
\hline Maestranza I $\mathrm{C}_{4}$ & Black & Wooden stick & $\mathrm{U}$ & O-I years & MASMA \\
\hline PLM 83524 & Black & Bone & $\mathrm{U}$ & Undetermined & MASMA \\
\hline MNHN I0955 & Red & Turban cord & $\mathrm{M}$ & Undetermined & MNHN \\
\hline MNHN I0988 & Red & Turban cord & $\mathrm{F}$ & Adult & MNHN \\
\hline MNHN Caja 72 & Red & Reeds & $\mathrm{U}$ & Undetermined & MNHN \\
\hline MNHN I IO4O & Red & Reeds & $\mathrm{U}$ & Child & MNHN \\
\hline Morro I $\mathrm{TIC}_{5}$ & Black & Reeds & $\mathrm{U}$ & 2-6 months & MCHAP \\
\hline
\end{tabular}

Nоте: F, female: M, male; U, undetermined; Complex, either black or red or a variation; MASMA, Museo Arqueológico San Miguel de Azapa, Arica; MNHN, Museo Nacional de Historia Natural, Santiago; MCHAP, Museo Chileno de Arte Precolombino, Santiago. 
selected were MNHN I0955, MNHN I0988, MNHN I I040, and MNHN Caja 72. On the basis of radiocarbon dates obtained for other Arica red mummies, we predicted that these four red mummies would cluster around $2000 \mathrm{BC}$ (uncalibrated).

\section{RESULTS}

All the dates were calibrated using the OxCal V3.5 calibration program (Ramsey 2000). Table 3 shows the existing dates in years $\mathrm{BP}$ and the calibrated dates in years $\mathrm{BC}$ for all the Chinchorro mummies from Arica, using a two-sigma range. From this table a general trend can be seen, with the black mummies the oldest followed by the red and then by the natural mummies. One mudcoated mummy fell between the black and the red mummies, and two natural mummies fell among the red style.

Table 4 shows the radiocarbon dates of the I 5 newly dated Chinchorro mummies from Arica. All the dates were corrected for delta ${ }^{12} \mathrm{C} /{ }^{13} \mathrm{C}$ and calibrated using the
OxCal V3.5 program. These dates show the black style as the oldest, followed by the red, but there are two natural mummies fitting within the black and red ones. In addition, there is now one black mummy, Morro I Ti $\mathrm{C}_{5}$, that is an outlier dating to $2700-900 \mathrm{cal} \mathrm{BC}$ (two-sigma). The presence of Morro I T23 Ci2, a mud-coated mummy dated to 3640-3370 cal BC (two-sigma), fits the trend presented in table 3 . Table 5 and figures 4 and 5 show a summary of all previous radiocarbon dates and the current ones arranged by median and type of mummy, respectively.

\section{DISCUSSION}

Organic materials including skeletons and mummies of early preceramic sites are rare. Although the sample size is small for 3,000 years of mummification, some trends are apparent. In all the cemeteries studied, the black mummies were older than the red. Moreover, the early cemeteries had only black and natural mummies, while

TABLE 3

Previously Dated Arica Region Chinchorro Mummies and Their Ages

\begin{tabular}{|c|c|c|c|c|c|c|c|}
\hline $\begin{array}{l}\text { Site and } \\
\text { Mummy }\end{array}$ & Style & Lab Number & Sample & $\begin{array}{l}{ }^{{ }^{14} \mathrm{C} \text { Age }} \\
(\text { Years BP) }\end{array}$ & Error I $\sigma$ & $\begin{array}{l}\text { Calibrated } \\
\text { Range }^{\mathrm{a}} 2 \sigma \\
\left(\text { Years BC) }^{2}\right.\end{array}$ & $\begin{array}{l}\text { Reference for } \\
\text { Uncalibrated } \\
\text { Dates }\end{array}$ \\
\hline Morro I-6 Ti 3 & Natural & I-I 4958 & Muscle & 3560 & IOO & $2200-1600$ & $\begin{array}{l}\text { Focacci and Chacón } \\
\text { (I989) }\end{array}$ \\
\hline Morro I T28C9 & Mud & I-I365I & Muscle/lung & 3670 & IOO & $2400-1700$ & Allison et al. (I984) \\
\hline Morro I-6 T27 & Natural & GX-I826I & Cartilage & 3750 & $\mathrm{I} 4 \mathrm{O}$ & $2600-1750$ & $\begin{array}{l}\text { Focacci and Chacón } \\
\text { (1989) }\end{array}$ \\
\hline Morro I T28C 8 & Natural & I-I3656 & Muscle & 3790 & I 40 & $2650-1750$ & Allison et al. (I984) \\
\hline Morro I T28C22 & Natural & I-I 3652 & Lung & 3830 & IOO & $2600-1950$ & Allison et al. (I984) \\
\hline Morro I-6 T39 & Natural & GX-I8259 & Muscle & 3880 & 70 & $2570-2520$ & $\begin{array}{l}\text { Focacci and Chacón } \\
\text { (1989) }\end{array}$ \\
\hline Morro I-6 $\mathrm{T}_{53}$ & Natural & GX-I 8262 & Cartilage & 3895 & 75 & $\begin{array}{l}2500-2190 \\
2180-2140 \\
2580-2190\end{array}$ & $\begin{array}{l}\text { Focacci and Chacón } \\
\text { (1989) }\end{array}$ \\
\hline Morro I-6 T23 & Natural & GX-I 8263 & Liver & 4010 & 75 & $\begin{array}{l}2 \text { I } 80-2 \text { I } 40 \\
2900-2250\end{array}$ & $\begin{array}{l}\text { Focacci and Chacón } \\
\text { (1989) }\end{array}$ \\
\hline Morro $\mathrm{I}_{2} \mathrm{~T}_{2} \mathrm{C}_{7}$ & Red & I-I 3543 & Wood & 4040 & IOO & $2900-2300$ & Allison et al. (I984) \\
\hline PLM 8 & Red & GAK-58 I I & Wood & 4090 & 105 & $2900-2300$ & Núñez (I976) \\
\hline Morro I-5 (MI) & Red & GX-I70I9 & Liver & $4 \mathrm{I} 2 \mathrm{O}$ & 75 & $2890-2490$ & Guillén (I992:I79) \\
\hline Morro I T2 ICI & Natural & I-I $354 \mathrm{I}$ & Muscle & 4200 & IOO & $3050-2450$ & Allison et al. (I984) \\
\hline Morro I-6 $\mathrm{T}_{9}$ & Natural & GX-I 8260 & Liver & 4310 & I 45 & $3400-2450$ & $\begin{array}{l}\text { Focacci and Chacón } \\
\text { (1989) }\end{array}$ \\
\hline Morro I Ti9 & Red & I-I 3650 & Muscle & 4350 & 280 & $3700-2200$ & Allison et al. (I984) \\
\hline Morro I $\mathrm{T}_{7} \mathrm{C}_{\mathrm{I}}$ & Red & Beta-40956 & Muscle & 4520 & 90 & $3500-2900$ & Standen (I99I) \\
\hline Morro I T25 66 & Mud & I-I 3542 & Muscle & 4570 & IOO & $3650-2900$ & Allison et al. (I984) \\
\hline Maderas Enco I CI & Black & GX-I7464 & Wood & 4750 & I 55 & $3950-3000$ & Arriaza (I995b:4I) \\
\hline Morro I $\mathrm{TiC}_{4}$ & Black & I-I 3539 & Lung & 5160 & IIO & $4250-3700$ & Vera (I98I) \\
\hline Arica & Black & GAK-9902 & Wood & 5240 & I IO & $4350-3750$ & Allison et al. (I984) \\
\hline Chinchorro I $\mathrm{TIC}_{2}$ & Black & GAK-I 5083 & Wood & 5560 & 175 & $4800-3950$ & $\begin{array}{l}\text { Muñoz, Arriaza, and Auf- } \\
\text { derheide (I993), Auf- } \\
\text { derheide, Muñoz, and } \\
\text { Arriaza (I993) }\end{array}$ \\
\hline Chinchorro I TICI & Black & GX-I 5084 & Wood & 6070 & 285 & $5600-4300$ & $\begin{array}{l}\text { Muñoz, Arriaza, and Auf- } \\
\text { derheide (I993), Auf- } \\
\text { derheide, Muñoz, and } \\
\text { Arriaza (I993) }\end{array}$ \\
\hline
\end{tabular}

${ }^{a}$ The probability has been calculated relative to the $95.4 \%$ significance level. 
TABLE 4

Radiocarbon Dates of New Chinchorro Mummies from Arica

\begin{tabular}{|c|c|c|c|c|c|c|c|c|c|c|c|}
\hline $\begin{array}{l}\text { Site and } \\
\text { Mummy }\end{array}$ & Style & $\begin{array}{c}\text { Lab } \\
\text { Number }\end{array}$ & Sample Type & $\begin{array}{l}{ }^{{ }^{4} 4} \mathrm{C} \text { Age } \\
(\text { Years BP) }\end{array}$ & Error I $\sigma$ & $\delta^{13} \mathrm{C} /{ }^{12} \mathrm{C}$ & $\begin{array}{l}\text { Corrected } \\
{ }^{14} \mathrm{C} \text { Age } \\
\text { (Years BP) }\end{array}$ & $\begin{array}{c}\text { Calibrated } \\
\text { Range I } \sigma \\
\text { (Years BC) }\end{array}$ & Probability & $\begin{array}{c}\text { Calibrated } \\
\text { Range } 2 \sigma \\
\text { (Years BC) }\end{array}$ & Probability \\
\hline MNHN IIO4O & Red & DRI-3454 & Reeds & 3296 & 210 & -27.62 & 3254 & I900-I250 & 68.2 & $2200-900$ & 95.4 \\
\hline Morro I $\mathrm{TIC}_{5}$ & Black & DRI-3453 & Reeds & 3488 & 317 & -27.97 & 3440 & $2200-1300$ & 68.2 & $2700-900$ & 95.4 \\
\hline MNHN I0988 & Red & DRI-3446 & Cord & 3618 & 83 & -23.69 & 3640 & $2 \mathrm{I} 4 \mathrm{O}-\mathrm{I} 88 \mathrm{O}$ & 68.2 & $2300-1700$ & 95.4 \\
\hline Morro I $\mathrm{T}_{23} \mathrm{C}_{5}$ & Natural & DRI-3390 & Muscle & 3818 & 60 & -20.47 & $389 \mathrm{I}$ & $2470-2290$ & 68.2 & $2560-2530$ & I.9 \\
\hline MNHN I0955 & Red & DRI-3447 & Cord & 3933 & I 43 & -25.37 & 3927 & $\begin{array}{l}2620-2190 \\
2160-2140\end{array}$ & $\begin{array}{r}66.8 \\
\mathrm{I} .4\end{array}$ & $\begin{array}{l}2500-2190 \\
2900-2000\end{array}$ & $\begin{array}{l}93.5 \\
95.4\end{array}$ \\
\hline Morro I $\mathrm{T}_{7} \mathrm{C}_{5}$ & Red & DRI-345 I & Reeds & $4 \mathrm{I} 74$ & 86 & $-25.7 \mathrm{I}$ & $4 \mathrm{I} 63$ & $\begin{array}{l}2880-2830 \\
2820-2660 \\
2650-2620\end{array}$ & $\begin{array}{r}\mathrm{I} 3.3 \\
47.7 \\
7.2\end{array}$ & $\begin{array}{l}2920-2550 \\
2540-2490\end{array}$ & $\begin{array}{r}9 \mathrm{I} . \mathrm{I} \\
4.3\end{array}$ \\
\hline Morro I T7C6 & Red & DRI-3389 & Wool, hair, and muscle & 4093 & $8 \mathrm{I}$ & -20.57 & $4 \mathrm{I} 64$ & $\begin{array}{l}2880-2830 \\
2820-2660 \\
2650-2620\end{array}$ & $\begin{array}{r}12.9 \\
49.2 \\
6.1\end{array}$ & $\begin{array}{l}2910-2550 \\
2540-2490\end{array}$ & $\begin{array}{r}92.4 \\
3.0\end{array}$ \\
\hline Morro I $\mathrm{T}_{25} \mathrm{C}_{5}$ & Red & ETH-I 8326 & Wool and hair & AMS & 75 & -22.5 & 4260 & $\begin{array}{l}3020-2980 \\
2930-2850\end{array}$ & $\begin{array}{r}5.1 \\
5.6 \\
28.3\end{array}$ & $\begin{array}{l}3090-3060 \\
3040-2620\end{array}$ & $\begin{array}{r}\text { I. } 6 \\
93.8\end{array}$ \\
\hline MNHN Caja 72 & Red & DRI-3455 & Reeds & 4297 & I 35 & -26.48 & 4273 & $\begin{array}{l}2820-2680 \\
3090-3060 \\
3040-2830 \\
2820-2660\end{array}$ & $\begin{array}{r}34.2 \\
3.0 \\
35.6 \\
26.2\end{array}$ & $3350-2450$ & 95.4 \\
\hline Morro I $\mathrm{T}_{7} \mathrm{C}_{4}$ & Red & DRI-3388 & Muscle & 4394 & 54 & -19.62 & $448 \mathrm{I}$ & $\begin{array}{l}2650-2620 \\
3340-3 \text { I } \\
3 \text { I } 40-3090\end{array}$ & $\begin{array}{r}3.4 \\
5 \mathrm{I} .6 \\
\mathrm{I} 3.2\end{array}$ & $\begin{array}{l}3360-3010 \\
2980-2960\end{array}$ & $\begin{array}{r}92.6 \\
1.2\end{array}$ \\
\hline Morro I $\mathrm{T}_{23} \mathrm{C}_{12}$ & Mud & DRI-3448 & Muscle & 4633 & 55 & $-\mathrm{I} 9.56$ & $472 \mathrm{I}$ & $\begin{array}{l}3060-3040 \\
3630-3560 \\
3540-3490 \\
3440-3370\end{array}$ & $\begin{array}{r}3.4 \\
24.8 \\
17.1 \\
26.3\end{array}$ & $\begin{array}{l}2950-2920 \\
3640-3370\end{array}$ & $\begin{array}{r}\text { I. } 6 \\
95.4\end{array}$ \\
\hline Maestranza I CI & Natural & ETH-I 8324 & Bone & AMS & 70 & $-2 \mathrm{I} \cdot 3$ & 5170 & $\begin{array}{l}3220-4200 \\
4550-3930 \\
3880-3800\end{array}$ & $\begin{array}{r}20.3 \\
2.3 \\
48.5 \\
17.4\end{array}$ & $\begin{array}{l}4230-4190 \\
4170-3790\end{array}$ & $\begin{array}{r}4.8 \\
90.6\end{array}$ \\
\hline Maestranza I $\mathrm{C}_{4}$ & Black & DRI-3452 & Wood & 5438 & 170 & -24.06 & 5453 & $4460-4040$ & 68.2 & $4700-3900$ & 95.4 \\
\hline Morro I TiоB & Complex & DRI-3449 & Vegetable matrix & $54 \mathrm{I} 4$ & 58 & -19.79 & 5498 & $\begin{array}{l}4450-4420 \\
4400-4380 \\
4370-4320 \\
4290-4250\end{array}$ & $\begin{array}{r}\mathrm{I} 2.0 \\
5.4 \\
3 \mathrm{I} . \mathrm{I} \\
\mathrm{I} 9.8\end{array}$ & $4460-4220$ & 95.4 \\
\hline Morro I ТiоB & Complex & DRI-3450 & Bone & 5434 & 59 & $-\mathrm{I} 8.88$ & 5533 & $4460-4330$ & 68.2 & $4500-4240$ & 95.4 \\
\hline PLM 83524 & Black & DRI-3445 & Bone & 5744 & 310 & -22.06 & $579 \mathrm{I}$ & $5050-4300$ & 68.2 & $5400-3900$ & 95.4 \\
\hline
\end{tabular}


TABLE 5 Minimum, Median, and Maximum Values of Calibrated Dates for All Chinchorro Mummies from Arica Using a Two-Sigma Confidence-Interval-Level OxCal V3.5

\begin{tabular}{|c|c|c|c|c|c|c|}
\hline $\begin{array}{l}\text { Site and } \\
\text { Mummy }\end{array}$ & Style & Sex & $\begin{array}{c}\text { Biological } \\
\text { Age }\end{array}$ & $\begin{array}{l}\text { Minimum of } \\
\text { Calibration Range } \\
\text { at } 2 \sigma(\mathrm{BC})\end{array}$ & Median & $\begin{array}{c}\text { Maximum of } \\
\text { Calibration Range } \\
\text { at } 2 \sigma(\mathrm{BC})\end{array}$ \\
\hline MNHN I IO4O & Red & $\mathrm{U}$ & Child & 900 & I 550 & 2200 \\
\hline Morro I $\mathrm{TiC}_{5}$ & Black & $\mathrm{U}$ & 2-6 months & 900 & I 800 & 2700 \\
\hline Morro I-6 TI 3 & Natural & $\mathrm{F}$ & I 8-20 years & 1600 & I900 & 2200 \\
\hline MNHN I0988 & Red & $\mathrm{F}$ & Adult & I 700 & 2000 & 2300 \\
\hline Morro I T28C9 & Mud & $\mathrm{F}$ & $25-30$ years & I 700 & 2050 & 2400 \\
\hline Morro I-6 T27 & Natural & M & $35-40$ years & I750 & 2175 & 2600 \\
\hline Morro I T28C8 & Natural & M & Adult & I750 & 2200 & 2650 \\
\hline Morro I T28C22 & Natural & M & $35-40$ years & I950 & 2275 & 2600 \\
\hline Morro I-6 T39 & Natural & $\mathrm{F}$ & I4-I 6 years & 2140 & 2355 & 2570 \\
\hline Morro I-6 T53 & Natural & $\mathrm{F}$ & I $8-20$ years & 2140 & 2360 & 2580 \\
\hline Morro I $\mathrm{T}_{2} \mathrm{C}_{5}$ & Natural & $\mathrm{F}$ & $25-30$ years & 2190 & 2375 & 2560 \\
\hline MNHN I0955 & Red & M & $\mathrm{U}$ & 2000 & 2450 & 2900 \\
\hline Morro I-6 T23 & Natural & M & 25 years & 2250 & 2575 & 2900 \\
\hline Morro I $\mathrm{T}_{23} \mathrm{C}_{7}$ & Red & $\mathrm{F}$ & 20-23 years & 2300 & 2600 & 2900 \\
\hline PLM 8 & Red & & & 2300 & 2600 & 2900 \\
\hline Morro I-5 (MI) & Red & M & $25-28$ years & 2490 & 2690 & 2890 \\
\hline Morro I T7C6 & Red & M & Infant & 2490 & 2700 & 2910 \\
\hline Morro I $\mathrm{T}_{7} \mathrm{C}_{5}$ & Red & M & $2-3$ years & 2490 & 2705 & 2920 \\
\hline Morro I T2 ICI & Natural & $\mathrm{F}$ & I2-I3 years & 2450 & 2750 & 3050 \\
\hline Morro I $\mathrm{T}_{25} \mathrm{C}_{5}$ & Red & $\mathrm{F}$ & o-2 months & 2620 & 2855 & 3090 \\
\hline MNHN Caja 72 & Red & $\mathrm{U}$ & $\mathrm{U}$ & 2450 & 2900 & 3350 \\
\hline Morro I-6 $\mathrm{T}_{9}$ & Natural & M & 60 years & 2450 & 2925 & 3400 \\
\hline Morro I Tig & Red & $\mathrm{F}$ & Infant & 2200 & 2950 & 3700 \\
\hline Morro I $\mathrm{T}_{7} \mathrm{C}_{4}$ & Red & $\mathrm{F}$ & A & 2920 & 3140 & 3360 \\
\hline Morro I $\mathrm{T}_{7} \mathrm{C}_{\mathrm{I}}$ & Red & $\mathrm{F}$ & I4-I 6 years & 2900 & 3200 & 3500 \\
\hline Morro I T25C6 & Mud & M & 5-6 years & 2900 & 3275 & 3650 \\
\hline Maderas Enco I $\mathrm{C}_{\mathrm{I}}$ & Black & M & I7-I 8 years & 3000 & 3475 & 3950 \\
\hline Morro I T23 $\mathrm{CI}_{2}$ & Mud & $\mathrm{F}$ & 20-25 years & 3370 & 3505 & 3640 \\
\hline Morro I TiC4 & Black & $M$ & $30-34$ years & 3700 & 3975 & 4250 \\
\hline Maestranza I CI & Natural & $M ?$ & I4-I 5 years & 3790 & 4010 & 4230 \\
\hline Arica & Black & & & 3750 & 4050 & 4350 \\
\hline Maestranza I $\mathrm{C}_{4}$ & Black & $\mathrm{U}$ & O-I years & 3900 & 4300 & 4700 \\
\hline Morro I TioB (VEG.) & Complex & $\mathrm{F}$ & Adult & 4220 & 4340 & 4460 \\
\hline Morro I TioB (BONE) & Complex & $\mathrm{F}$ & Adult & 4240 & 4370 & 4500 \\
\hline Chichorro I $\mathrm{TiC}_{2}$ & Black & $\mathrm{U}$ & $3-4$ years & 3950 & 4375 & 4800 \\
\hline PLM 83524 & Black & $\mathrm{U}$ & $\mathrm{U}$ & 3900 & 4650 & 5400 \\
\hline Chinchorro I TICI & Black & $\mathrm{U}$ & $3-4$ years & 4300 & 4950 & 5600 \\
\hline
\end{tabular}

other cemeteries had black, red, and natural ones. Using two-sigma minimum, median, and maximum calibrated values, there are three main clusters of mummification styles, a black (ca. 4950-3475 cal BC), a red (3200-2450 cal BC), and a natural (2375-I900 cal BC). The new batch of radiocarbon dates confirms that the black mummies are the oldest, followed by the red. However, there are some surprises. The natural mummies tend to cluster toward the end of the artificial mummification period. One male I4-I 5 years old (Maestranza I CI), naturally mummified, was dated to $40 \mathrm{Io}$ cal BC (median). He was buried next to Maestranza I $\mathrm{C}_{4}$, an infant prepared using the black style, dated to 4300 cal BC (median). However, if we use the two-sigma distribution, the dates of these mummies overlap and can be considered contemporaneous (see table 5 and fig. 4). Both bodies were buried in extended position and found next to nine other bodies with varying degrees of artificial mummification (see table I). Although all the bodies from the Maestranza site were extremely fragmented, Maestranza I CI was found lying on top of Maestranza I $\mathrm{C}_{4}$ and thus the two could archaeologically be considered as a unit, perhaps buried a few decades apart. In addition, the Maestranza I $C_{I}$ mummy fits in the middle of the black period and prior to two typical black mummies: Morro I $\mathrm{TIC}_{4}$, an adult male, and Maderas Enco I CI, a young male. This certainly raises the question what the status of this individual was and why he was not artificially mummified. Ideally nDNA and/or HLA markers will shed light on whether this individual is genetically related to other individuals in the cemetery or represents an outsider. The second intriguing issue is that there are three additional natural mummies (Morro I-6 T23, Morro I T2ICI, Morro I-6 T9, an adult male, a young female, and an adult male respectively) fitting within the red period (see table 5 and figs. 4 and 5). They are placed at different times, but using a two-sigma value they can be considered contemporaneous with several red mummies (fig. 4). In addition, about I 550-2000 cal BC (median) there are also two red mummies, all with simpler mum- 


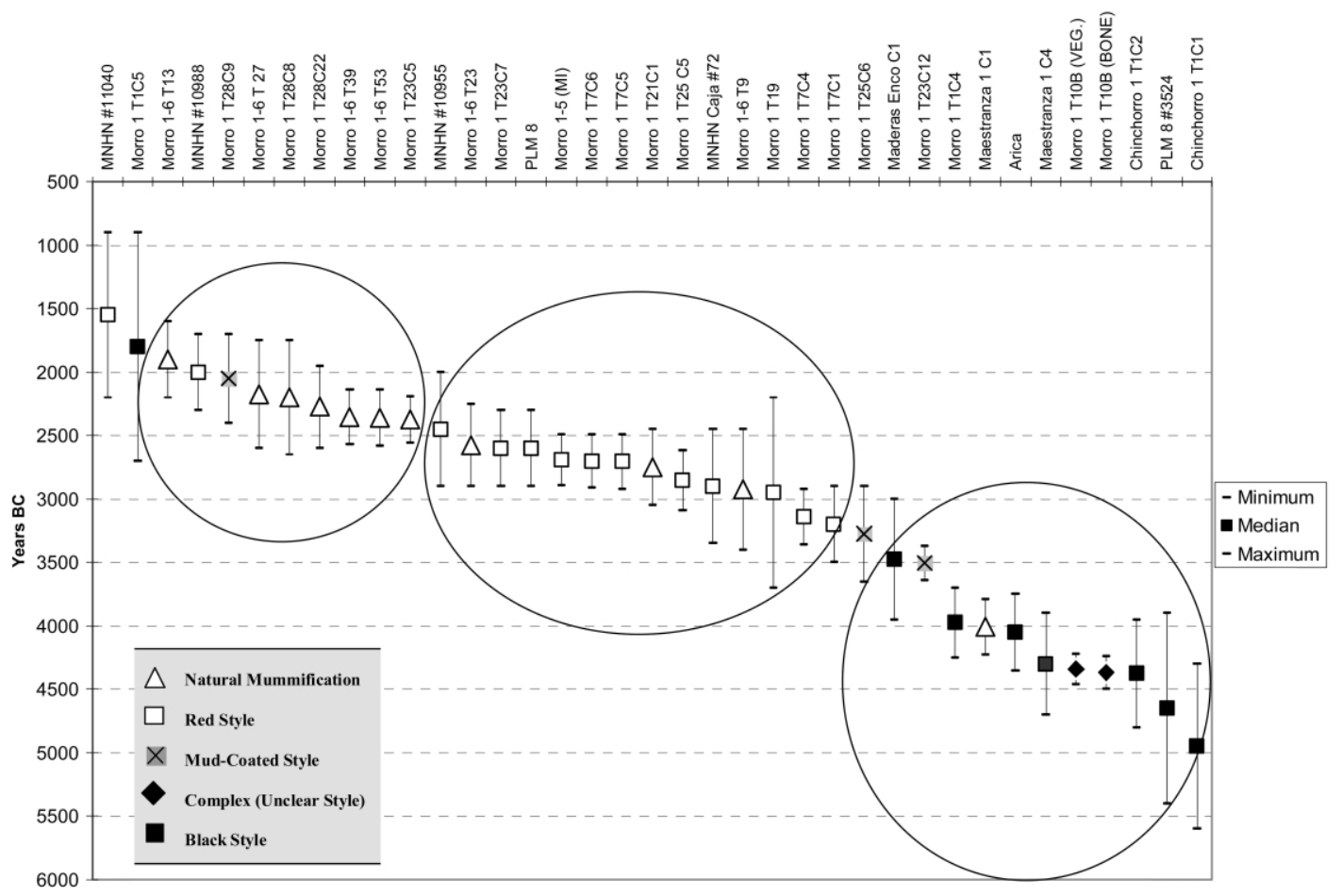

FIG. 4. Calibrated dates (arranged by median).

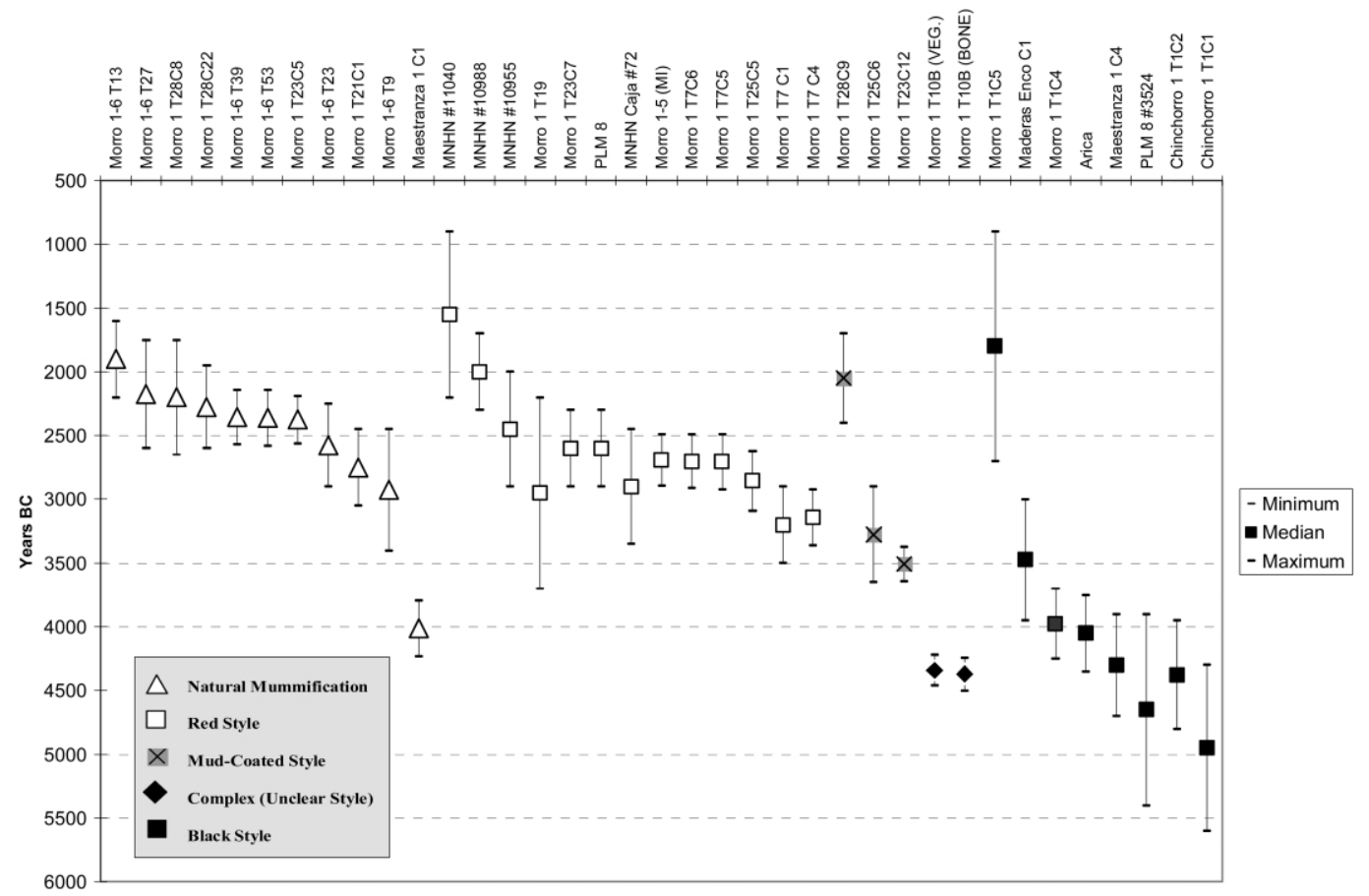

Fig. 5. Minimum, median, and maximum calibrated dates (arranged by type of mummy). 
mification techniques than usual (MNHN I0988 and MNHN I I040, an adult female and a child, respectively), clustering among the natural ones. It is still unclear how the mud-coated style changed over time and what its cultural significance was. If more of these bodies are found, they will need to be radiocarbon-dated.

The relevant issue here is that cultural practices were changing over time, but within each style some juvenile and older individuals of both sexes were not granted the full rite of artificial mummification. Thus, Arriaza's and Standen's hypotheses are both partially correct. The 36 radiocarbon dates on 35 mummies (table 5) indicate that the evolutionary style classification is valid but that the natural mummies fitting between the black and red mummification styles are a real cultural phenomenon, not the product of biased or contaminated samples. So far this is true for Morro I and Maestranza I sites. The I 800 cal BC (median) date for Morro I TIC5, a black mummy, however, is completely out of sequence. The materials dated for this mummy and for the late red mummies were reeds of the external wrapping. This extreme discrepancy for Morro $\mathrm{TI}_{5} \mathrm{C}_{5}$ is puzzling, and contamination of the sample or rewrapping of the mummy by later groups is a possibility. If we had two radiocarbon dates for each mummy with conflicting dates, one from the inner structure of the mummy and the other from the outside, we might learn something about the use and reuse of the cemeteries and mummies by ancient populations. Therefore, future studies will need to determine to what extent ancient cultural mortuary practices affected Chinchorro burial chronology. The archaeological record is dynamic; what we see is not always the way things were. Rather than a static moment in the past, archaeological finds may instead be several moments or events intermingling like a collage (see Williams and Beck 200I). Even today in the Atacama Desert, in Arica, for example, when local farmers come across prehistoric or historic bones they often rebury them in twenty-first-century garments or plastic bags. Likewise, it is possible that in some cases subsequent generations of Chinchorro people saw or visited older mummies, wrapping them in new mat shrouds. This certainly would affect our chronological evolutionary typology, making older mummies chronologically younger.

Funerary practices are not a random phenomenon; on the contrary, they are determined, among the main variables, by traditions, responsibilities toward the dead, the social position of the deceased, the social structure of the population, and beliefs about an afterlife (see, e.g., Arriaza I988, Chapman, Kinnes, and Randsborg I99I, and Parker Pearson 2000). Chinchorro mummification practices starting around 6000 cal $\mathrm{BC}$ (for the Camarones site) may have begun as a product of grief, with children being artificially mummified and adults not. In addition, the data presented in table 5 show that all the infants radiocarbon-dated received artificial mummification regardless of site and time. However, this child mummification preference does not necessarily apply to the situation thousands of years later, when we find individuals of all ages receiving complex treatment.
Using a two-sigma distribution (between MNHN I0955 and Chinchorro I TICI, that is, between 2450 and $4950 \mathrm{cal} \mathrm{BCl}$, it is notable that at least 4 of the 25 radiocarbon-dated bodies received minimal mortuary treatment (natural mummification). Therefore, it seems that there is a case for differential rites or social position. Although the Chinchorro had few grave goods, they were living year-round on the coast and must have been competing for mates and resources. Confrontation and trauma are evident in their bones (Standen and Arriaza 2000), and therefore one hypothesis is that the few bodies with natural mummification may represent social outliers (nonlocals) of a low sociocultural position. This hypothesis is testable using aDNA or bone chemistry data such as strontium, oxygen isotope, and trace-element analyses (Verano and De Niro I 993, Knudson et al. 2004). However, some of the main factors leading to differential treatment in band-level societies appear to be belief in the supernatural, the charisma or personality of the individual, responsibility toward the ancestors, myth about a universal order, and cause of death (Arriaza I988, Carr and Neitzel I995). Thus an alternative explanation is possible though harder to prove. Perhaps these four individuals, three males and one female (Morro I-6 T23, Morro I T2ICI, Morro I-6 T9, and Maestranza ICI), ranging from juvenile to older adults, broke community rules or died under unusual circumstances and were therefore undeserving of mummification.

In brief, our study shows that Chinchorro mortuary practices changed from black to red and that, contrary to our previous notions, mummification was applied selectively. Not everyone was artificially mummified in each period. All infants, however, received complex treatment independent of location and time, and therefore it seems that infancy was sufficient or at least a determining factor for being granted artificial mummification. If more natural mummies were radiocarbondated, they might cluster with those artificially prepared. The few grave goods do not support status differences between the different types of mummies. Thus, rather than considering the body treatment within a time frame (red or black period) as a vertical social differentiation, we are inclined toward the idea of an ideological-circumstantial treatment of the dead. Future studies will be needed to confirm our hypothesis that Chinchorro infants were always mummified and determine whether more natural mummies cluster among the artificially prepared ones. If the latter proves to be the case, Chinchorro differential treatment of the dead will be an even more complex issue for investigation.

\footnotetext{
References Cited

ALLISON, MARVIN, GUILLERMO FOCACCI, BERNARDO ARRIAZA, VIVIEN STANDEN, MARION RIVERA, AND JEROLD LOWENSTEIN. I984. Chinchorro, momias de preparación complicada: Métodos de momificación. Chungara I3: I $55-73$.

ALVAREZ, LUIS. I969. Un cementerio precerámico con momias de preparación complicada. Rehue 2:18 I-90.
} 
A R R I A Z A, B E R N A R D O. I988. Modelo bioarqueológico para la búsqueda y acercamiento al individuo social. Chungara $2 \mathrm{I}$ : 9-32.

. I994a. Tipología de las momias chinchorro y evolución de las prácticas momificación. Chungara 26:I I-24.

- I994b. Tipología de las momias chinchorro: Respuesta a Rivera, Schiappacasse y Wise. Chungara 26:4I-47.

- I995a. Chinchorro bioarchaeology: Chronology and mummy seriation. Latin American Antiquity 6(1):35-55 - I $995 \mathrm{~b}$. Beyond death: The Chinchorro mummies of ancient Chile. Washington, D.C.: Smithsonian Institution Press. AUFDERHEIDE, ARTHUR, IVAN MUÑZ, AND BERNARDO ARRIAZA. I993. Seven Chinchorro mummies and the prehistory of northern Chile. American Journal of Physical Anthropology 91:I89-20I.

CARR, CHRistopher, AND jill Neitzel. I995. Style, society, and person: Archaeological and ethnological perspectives. New York: Plenum Press.

CHAPMAN, R., I. KINNES, AND K. RANDSBORG. Editors. I98I. The archaeology of death. Cambridge: Cambridge University Press.

DOU B R A VA, M. 200I. Radiometric evaluation of the prehistoric mortuary practices of the Chinchorro culture in northern Chile. Master's thesis, University of Nevada, Las Vegas, Nev.

F O CACCI, GUILLERMO, AND SERGIO CHACÓN. I989. Excavaciones arqueológicas en los faldeos del Morro de Arica, sitios Morro I/6 y 2/2. Chungara 22: 15-62.

GUILLÉN, SONIA. I 992 . The Chinchorro culture: Mummies and crania in the reconstruction of Preceramic coastal adaptation in the south central Andes. Ph.D. diss., University of Michigan, Ann Arbor, Mich.

KNUDSON, K. J., T. D. PRICE, J. BUIKSTRA, AND D. E. B LOM. 2004. The use of strontium isotope analysis to investigate Tiwanaku migration and mortuary ritual in Bolivia and Peru. Archaeometry 46(I):5-I8.

MUÑOZ, IVAN, BERNARDO ARRIAZA, AND ARTHUR A U F D E R E IDE. Editors. I993. Acha-2 y el orígen del poblamiento humano de Arica. Arica: Ediciones Universidad de Tarapacá.

N Ú ÑEZ, LA UTARO. I976. Registro nacional de fechas radiocarbónicas del norte de Chile. Estudios Atacameños 4:74-123.

PARKER PEARSON, MICHAEL. 2000. The archaeology of death and burial. College Station: Texas A\&M University Press.

RAMSEY, BRONK. 2000. OxCal Version 3.5.

RIVERA, MARIO. I994. Comentario sobre el trabajo de Bernardo Arriaza: Tipología de las momias chinchorro y evolución de las prácticas de momificación. Chungara 26:25-34.

SCHIA P PACASSE, VIRGILIO. I994. Comentario al artículo tipología de las momias chinchorro de Bernardo Arriaza. Chungara 26:35-36.

S T A N DEN, VIVIEN. I99I. El cementerio Morro-I: Nuevas evidencias de la tradición funeraria Chinchorro (Period Arcaico, Norte de Chile). Master's thesis, Pontificia Universidad Católica del Perú, Lima, Peru.

- I997. Temprana complejidad funeraria de la cultura chinchorro (Norte de Chile). Latin American Antiquity 8(2):134-56.

STANDEN, VIVIEN, AND BERNARDO ARRIAZA. 2000. Traumas in the preceramic coastal populations of northern Chile: Violence or occupational hazards? American Journal of Physical Anthropology I I 2:239-49.

VERA, JA I ME. I98 I. Momias chinchorro de preparación complicada del Museo de Historia Natural de Valparaíso: 3290 y 3060 a.C. Anales del Museo de Historia Natural de Valparaíso I 4:5-I7.

VERANO, JOHN W., AND MICHAEL J. DE NIRO. I993. "Locals or foreigners? Morphological, biometric, and isotopic approaches to the question of group affinity in human skeletal remains recovered from unusual archaeological contexts, "in Investigations of ancient human tissue: Chemical analysis in anthropology. Edited by M. K. Sandford, pp. 36I-86. New York: Gordon and Breach.

WILLiAMS, SLOAN, AND LANE BECK. 200I. Symposium:
Interacting with the dead: Secondary burial and cultural modifications of humans remains. Annual Meeting of the Society for American Archaeology, New Orleans, La.

WISE, KAREN. I994. Comentario sobre tipología de las momias chinchorro y evolución de las prácticas de momificación de Bernardo Arriaza. Chungara 26:35-36.

\section{The Advent of Herding in Southern Africa: Early AMS Dates on Domestic Livestock from the Kalahari Desert ${ }^{1}$}

LAWRENCE H. ROBBINS, ALEC C. CAMPBELL, MICHAEL L. MURPHY, GEORGE A. BROOK, PRADEEP SRIVASTAVA, AND SHAW

B A D E N OR T Department of Anthropology, Michigan State University, East Lansing, MI 48824, U.S.A. (robbins@msu.edu) (Robbins)/P.O. Box 306, Crocodile Pools, Gaborone, Botswana (Campbell)/Social Science Department, Kellogg Community College, 450 North Ave., Battle Creek, MI 490I7, U.S.A. (Murphy)/ Department of Geography, University of Georgia, Athens, GA 36802, U.S.A. (Brook and Srivastava)/ African Heritage Institute, I67, Buitenkant St., Gardens 800I, Cape Town, South Africa (Badenhorst). I II 05

[Supplementary material appears in the electronic edition of this issue on the journal's web page (http://www.journals.uchicago. edu/CA/home.html).]

In Africa cattle, sheep, and goats play a major role in the socioeconomic and ecological adaptations of many peoples, both past and present. For this reason as well as others, documenting the spread of domesticated livestock in Africa is a problem of major anthropological interest (Blench and MacDonald 2000, Hanotte et al. 2002). The development of desiccation in the Sahara is considered the major factor contributing to the spread of livestock from the Sahara into East Africa, where cattle

(C) 2005 by The Wenner-Gren Foundation for Anthropological Research. All rights reserved oOI I-3204/2005/4604-00IO\$IO.OO

I. Funding was provided by NSF grant BCS -03 I 38 I9. We thank the Office of the President in Botswana for granting permission to do this research and are grateful to $T$. Pule, former director of the National Museum and Art Gallery, and to the following colleagues who helped at Toteng: G. Babutsi, L. Thatlehego, S. Phaladi, A. Mabuse, S. Dingalo, and T. Shick. In addition, we are grateful to P. Segadika, F. Marshall, D. Gifford-Gonzalez, I. Plug, and K. Nkakobang. All of the fauna excavated in 2003, including the AMSdated livestock bones, were identified by S. Badenhorst at the Archaeozoology Lab at the Transvaal Museum in Pretoria. 
(Bos sp.) and goats are present at Pastoral Neolithic sites at Lake Turkana in northern Kenya by as early as 4,000-4,500 BP (Barthelme I985).

The questions of when and where livestock first entered southern Africa have been widely debated (Mitchell 2003: chap. 9). While the proposed routes vary, data gathered from historical linguistics, physical anthropology, genetics studies, and archaeology converge in suggesting that northern Botswana may have served as a major gateway for the initial spread of domesticated livestock into southern Africa (fig. I) (Westphal I 963, Ehret I982, Hausman I984, Sadr I998a). However, understanding of the chronology of the spread of livestock into the region has been hampered by the lack of pertinent AMS /accelerator mass spectrometry) radiocarbon dates obtained directly on livestock bones from the entire northern periphery of southern Africa. The establishment of an AMS chronology is crucial for documenting the spread of livestock because recent work at several key sites has demonstrated that sheep bones dated by AMS have proved to be considerably more recent than the bulk charcoal radiocarbon dates from the surrounding deposits had originally indicated (Sealy and Yates I996). In the sandy de- posits of the Kalahari, where small bones, charcoal fragments, and other objects can readily be moved considerable distances by burrowing animals such as springhare, it is essential to obtain AMS ages to establish an accurate perspective on the length of time livestock have been in the region. In this paper we present the first AMS dates obtained directly on domestic livestock bones from the postulated northern Botswana gateway area (table I).

\section{LAKE NGAMI AND THE TOTENG SITES: OVERVIEW}

The Toteng sites are located near Lake Ngami, at the junction of the Kunyere and Nchabe Rivers (figs. I, 2). After having dried up during the drought of I982, Lake Ngami is currently filling with water again. However, historical sources record a large lake and fairly dense aquatic vegetation in the mid-I8oos. Hippopotamus, rhinoceros, elephant, buffalo, kudu, reedbuck, giraffe, and other animals were common during the time of Livingstone, and the lake once teemed with fish (Livingstone I 858 ). Sediment analysis and single-aliquot regenerative (SAR) optically stimulated luminescence (OSL) dating (table 2) of fluvial sediments exposed in the walls of a



FIG. I. Localities mentioned in the text and the present-day distribution of tsetse and trypanosomiasis in southern Africa (modified after Gifford-Gonzalez 200o). 
TABLE I

Ages of Livestock Bones and Teeth from Toteng Based on Collagen Content

\begin{tabular}{|c|c|c|c|c|c|c|c|}
\hline Site & Square & Depth $(\mathrm{cm})$ & Domesticate & $\begin{array}{l}\text { Material } \\
\text { Dated }\end{array}$ & Laboratory ID & ${ }^{14} \mathrm{C}$ Age $(\mathrm{yr} \mathrm{BP} \pm 2 \sigma)$ & $\begin{array}{c}\text { Calibrated } \\
\text { Date (BC/AD) }\end{array}$ \\
\hline Toteng I & $\mathrm{K}$ & $75-80$ & Sheep (Ovis aries) & $\begin{array}{l}\text { Right astragalus } \\
2 \mathrm{~d} \text { and } 3 \mathrm{~d} \text { carpal, }\end{array}$ & Beta-I 86669 & $2,020 \pm 40$ & $\mathrm{BC}$ I IO $\pm \mathrm{AD} 70$ \\
\hline Toteng I & $\mathrm{L}$ & $70-75$ & Cow (Bos taurus) & right side & Beta-I904888 & $2,070 \pm 40$ & $\mathrm{BC} 190 \pm \mathrm{AD}_{20}$ \\
\hline Toteng I & $\mathrm{L}$ & $55-60$ & Cow (Bos taurus) & Upper molar & Beta-I 86670 & $I, 480 \pm 40$ & $\mathrm{AD} 530 \pm 650$ \\
\hline Toteng 3 & 7 & $30-35$ & Sheep/goat & Upper second molar & Beta-I 8667 I & $\mathrm{I}, \mathrm{I} 30 \pm 4 \mathrm{O}$ & $\mathrm{AD} 790 \pm 1000$ \\
\hline
\end{tabular}

dug well in the bed of the Nchabe River, $2 \mathrm{~km}$ southwest of Toteng, indicate strong flow into the Ngami Basin from the Kunyere and Nchabe at 4,200 \pm I,900 and at $2,200 \pm$ I, IOO years ago (UGAo4OSL-I 33 and I34). In addition, near Toteng 7 , about $\mathrm{I} \mathrm{km}$ southwest of Toteng I (fig. 2), lacustrine sediments in the small north-flowing tributary of the Nchabe include diatomite and organic, clay-rich beds indicating swampy conditions and backflooding of the Nchabe into the tributary due to rising lake levels at $5,300 \pm 600$ and $1,700 \pm 2,000$ years (UGAo4OSL-I47, I 50, and I55) (Robbins et al. I998). These findings support previous evidence of high levels of Lake Ngami around 4,000-3,000 and 2,000 years ago, when the sediments at Toteng I and 3 were accumulating (Shaw et al. 2003). A more extensive lake would have inundated the lower reaches of the Nchabe River valley, bringing a multitude of wetland resources to the Toteng area.

Pioneering work was carried out by Campbell and colleagues in I99I at Toteng, and additional excavations were conducted by a team from the University of Botswana (Campbell i992, Huffman I994, Reid, Sadr, and Hanson-James I998). It was established that the Toteng sites contained refuse middens with Bambata pottery, a hallmark of early domestic livestock in southern Africa, along with bones of cattle and either sheep or goats. Bambata pottery, named after the type-site of Bambata Cave in Zimbabwe, consists of generally small, thin-walled, delicate bowls and jars decorated with comb stamping and incision. Other sites known to contain Bambata pottery include widely scattered rock shelters and a number of open sites, most of the latter near Lake Ngami. It was also established at Toteng I, the site that had the best preservation of fauna, that wild game such as buffalo, impala, lechwe, tesessebe, warthog, zebra, steenbok, hippopotamus, crocodile, and fish occurred in the deposits with the domestic animals (Campbell I992). Both sites also yielded Later Stone Age microliths, bone arrow points or link shafts, and very small ostrich-eggshell beads. An age of about AD 240 was estimated for the Bambata pottery and livestock at Toteng on the basis of bulk radiocarbon ages (Campbell I992). Thus, the information from the Bambata middens at Toteng suggested the existence of a stone-tool-using people who had pottery and who hunted, fished, and herded livestock at the edge of Lake Ngami. Moreover, an underlying midden at Toteng I dated at 2,640 $= \pm 70 \mathrm{BP}$ included only wild game and lacked ceramics (Campbell I992). These findings suggested that there was an excellent chance of documenting the timing of the arrival of livestock in the area by direct dating of collagen in cow and sheep/goat bones and teeth by AMS. Therefore, we returned to Toteng in July 2003 with the primary objective of refining the chronology on domestic livestock through the use of AMS dating.

Excavations were carried out in arbitrary $5-\mathrm{cm}$ levels at Toteng sites I and 3, where a little over a meter of sandy deposits was found to overlie a thick layer of calcrete. Low frequencies of stone artifacts, varying from 3 to 56 specimens, were recovered in every $5-\mathrm{cm}$ level at Toteng I, where a block of seven I-meter squares was excavated. Formal retouched tools were rare but included backed segments, small thumbnail-shaped scrapers, and backed drills. All were characteristic Later Stone Age artifacts that are commonly found at other sites in Botswana as well as elsewhere in southern Africa. Apart from surface finds, Bambata pottery was found mainly between 35 and $60 \mathrm{~cm}$ at Toteng I and between 30 and $45 \mathrm{~cm}$ at Toteng 3 . Whereas identifiable bones were rarely found at Toteng 3, where seven I-meter squares were excavated, bones of catfish, tortoise, monitor lizard, crocodile, hippopotamus, buffalo, lechwe, sitatunga, hartebeest, steenbok, duiker, sheep, and cow were recovered from Toteng I. All of the wild animals, as well as those recovered previously by Campbell, are known to have inhabited the Lake Ngami area historically. Fish bones, mostly catfish, and tortoise-shell fragments were found in almost every $5-\mathrm{cm}$ level of Toteng I. The sitatunga found at 95-100 $\mathrm{cm}$ and the lechwe (IO5-IIo $\mathrm{cm}$ ) are both wetland antelope, suggesting the proximity of swamps adjacent to the lake or rivers-a conclusion consistent with the previously mentioned OSL-dated sediments. A unique discovery at Toteng I was the intentional burial (perhaps for ritual purposes) of a hippopotamus head, the remains of which extended between 90 and II $5 \mathrm{~cm}$ below the surface.

\section{DISCUSSION}

Many of the morphological differences between sheep and goat are not applicable to these species in southern Africa (Boessneck, Müller, and Teichert 1964, Prummel and Frisch I986, Badenhorst and Plug 2003). Nonetheless, the dated sheep astragalus was identified on the 


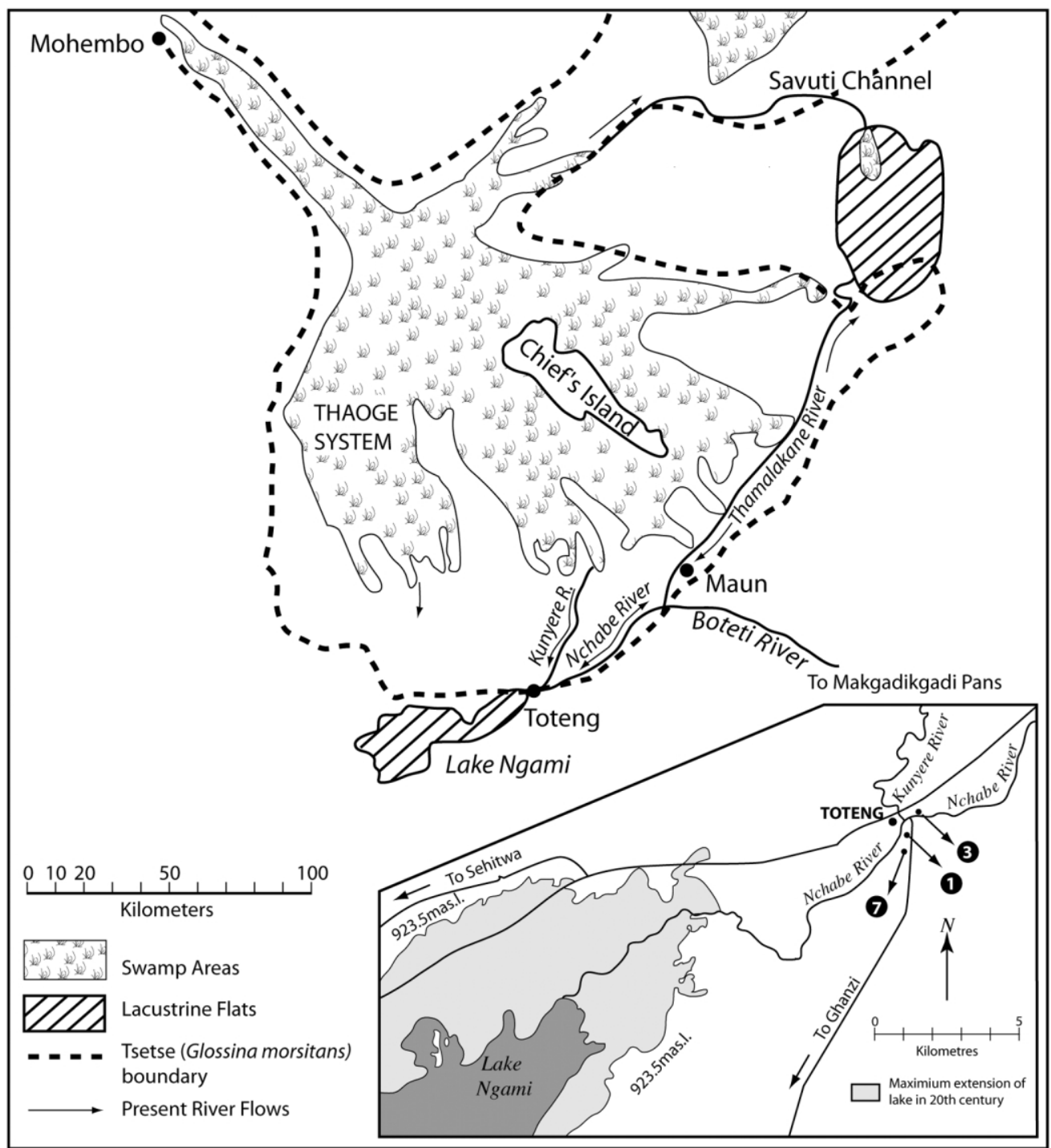

FIG. 2. The Toteng I and 3 archaeological sites and Lake Ngami in relation to the AD I850 tsetse fly (Glossina morsitans) boundary of Davies and Bowles (1976).

basis of the size of the specimen, the relative length, thickness, and position of the lateral versus medial dorsal facets, the relative length of the distal versus the proximal articulations, and the depth of the caput indentation (fig. 3). Taken together, these features distinguish this astragalus not only from wild antelope but also from goat. The dated cow second and third carpal fragment consists of the caudal section of the bone. In cattle this bone is more compressed and elongated than that of a wild antelope (fig. 3).

The very similar ages for the oldest cow and sheep bones at Toteng I imply that cattle and sheep arrived in the area together approximately 2,000 years ago. These findings are consistent with the interdisciplinary information suggesting that northern Botswana served as a gateway area for the dissemination of domesticated livestock in southern Africa. The initial appearance of livestock at Toteng is about 500-600 years earlier than the arrival of iron technology and livestock herding in both the Okavango Delta and the Tsodilo Hills areas north of Toteng (Denbow and Wilmsen I 986) (fig. I). Both of these areas have provided the best-understood "Early Iron Age" baseline sequences in the general region. Thus, the arrival of livestock at Toteng appears to predate the advent of iron technology in the region. In southern African archaeology most authorities have associated the arrival of iron technology with the spread of peoples speaking Bantu languages, while the Later Stone Age peoples who inhabited the area prior to the advent of iron smelting are most often considered to have been ancestral Khoi- 
Volume 46, Number 4, August-October 2005 | 675

TABLE 2

OSL Ages for Fluvial and Lacustrine Sediments in the Nchabe River Channel and Tributaries

\begin{tabular}{|c|c|c|c|c|c|c|c|c|}
\hline Laboratory ID & Sample ID & $\begin{array}{l}\text { Depth } \\
\text { (cm) }\end{array}$ & $\underset{(\mathrm{ppm})}{\mathrm{U}}$ & $\begin{array}{c}\text { Th } \\
\text { (ppm) }\end{array}$ & $\begin{array}{c}\mathrm{K} \\
(\%)\end{array}$ & $\begin{array}{c}\text { Dose Rate } \\
\text { (Gy/ka) }\end{array}$ & $\begin{array}{l}\text { Paleodose } \\
\text { (Gy) }\end{array}$ & $\begin{array}{l}\text { Age } \\
\text { (ka) }\end{array}$ \\
\hline UGAo4OSL-I 33 & Ngami-I I & I 80 & $0.3 \pm 0.04$ & $0.6 \pm 0.2$ & 0.09 & $0.3 \pm 0.03$ & I.4 \pm 0.6 & $4.2 \pm 1.9$ \\
\hline UGAO4OSL-I 34 & Ngami-I 2 & 80 & $0.4 \pm 0.04$ & $0.6 \pm 0.2$ & O.I & $0.4 \pm 0.03$ & $0.8 \pm 0.4$ & $2.2 \pm \mathrm{I} . \mathrm{I}$ \\
\hline UGAo4OSL-I 47 & TOTA7-I & 160 & $2.1 \pm 0.2$ & $0.8 \pm 0.8$ & 0.38 & $\mathrm{I} . \mathrm{O} \pm \mathrm{O} . \mathrm{I}$ & $5.4 \pm 0.4$ & $5.3 \pm 0.6$ \\
\hline
\end{tabular}

san-speaking peoples represented today by the San or "Bushmen" (Deacon and Deacon I999). The adoption of livestock in the Kalahari by the ancestors of modern Khoisan-speakers is consistent with the above gateway model and supports the closely connected view based on historical linguistics that Khwe herding peoples first diverged from the San in the Kalahari (Elphick I985).

Intertwined with the above issue is the length of time livestock have been herded in the Kalahari, an area that is best known for its hunting and gathering peoples. Some authorities have argued for a lengthy presence and impact of herding, while others have disputed this position, maintaining long-term integrity for the hunting and gathering lifestyle in the Kalahari (Wilmsen and Denbow I990, Solway and Lee I990, Smith and Lee I997, Smith 2005, Sadr I998b). The AMS ages clearly support the view that the utilization of livestock is of great antiquity in the area. Overall, the AMS dates from Toteng, combined with the historical data mentioned below, provide compelling evidence that domesticated livestock were present in this part of the Kalahari for a period of 2,000 years. At the same time, bones of wild game and fish imply that hunting, collecting, and fishing were practiced along with herding.

Cattle appear about 300 years later in South Africa than at Toteng (Plug I 996). Although there are few AMS ages available in the region, a comparison of the Toteng I sheep date with the oldest AMS dates obtained on sheep bones from South Africa reveals striking similarities. A sheep bone from Spoegrivier Cave in the Northern Cape yielded an age of 2,105 \pm 65 BP, while sheep bones from Blombos Cave, located at the southernmost tip of Africa, have produced ages of $1,960 \pm 50$ and I,880 \pm 55 BP (fig. I) (Sealy and Yates I994, Henshilwood I996). When the standard deviations are considered, the Toteng I and Spoegrivier dates overlap and the earlier of the Blombos dates is also quite close. These are the oldest direct ages for sheep in southern Africa, whereas numerous younger radiocarbon dates are available on Early Iron Age sites containing livestock. In contrast, Later Stone Age sites throughout southern Africa that have deposits dated to the period between ca. 2,500 and 5,000 BP contain only wild fauna (Mitchell 2003, Deacon and Deacon I999). This is also true for sites in the general Kalahari region such as Toteng 7 and the Tsodilo Hills rock shelters (Robbins et al. I998, 2000). These findings establish a likely baseline for the arrival and spread of sheep in southern Africa at approximately 2,00o years ago. The spread of sheep in the region appears to have been quite rapid, especially in contrast to the long period that it took for livestock herding to spread from East Africa to southern Africa.

There is growing interest in determining the rates at which food production spread throughout much of the world and understanding the factors that either contributed to or inhibited its dissemination (Diamond 2002). In the case of Africa, a pertinent question is why it took approximately 2,000-2,500 years for domesticated livestock to spread from the Lake Turkana region of East Africa to the Lake Ngami area of Botswana (a distance of at least $3,000 \mathrm{~km}$ ) and only a few hundred years or less for sheep to spread from the northern Kalahari to the southern tip of Africa (a distance of at least I,600 $\mathrm{km})$.

Work by Gifford-Gonzalez (2000) clearly shows that northern Botswana was situated at the southern edge of an area marked by a suite of major animal diseases that kill domestic livestock, especially cattle (fig. I). According to Gifford-Gonzalez, diseases such as bovine malignant catarrhal fever, East Coast fever, trypanosomiasis, and others were the main factors that inhibited the spread of livestock between eastern and southern Africa. When the distributions of the above diseases are lumped together, access to southern Africa for the dissemination of cattle, in particular, may have been virtually blocked over a substantial area extending from the Atlantic to the Indian Ocean. One of the most thoroughly documented of these animal diseases is trypanosomiasis or nagana, carried by tsetse flies (in the region in question, Glossina morsitans). Historical information shows that the Toteng sites were situated at or near the southern boundary of the tsetse-fly zone in Botswana (fig. 2) (Davies and Bowles I976). In I857 the explorer Charles Andersson (I 857:390) wrote that "a party of Griquas, about 20 in number, who were elephant-hunting to the northwest of the Ngami . . lost, prior to their return to the Lake, all their cattle by the bite of the Tsetse." Andersson himself first encountered tsetse just to the north of Lake Ngami along the Teoge ("Thaoge") River, a tributary that formerly flowed into the lake from the southwestern end of the Okavango Delta. However, he reported (p. 375) that the people who "inhabit the shores of the Ngami, are rich in sheep and goats, but possess comparatively few horned cattle." Relatively minor changes in rainfall and temperature would have had a significant impact on the tsetse-fly boundary and the ability to keep cattle in the immediate area. A slight drop in temperature 2,000 years ago would have shifted the boundary to the north 


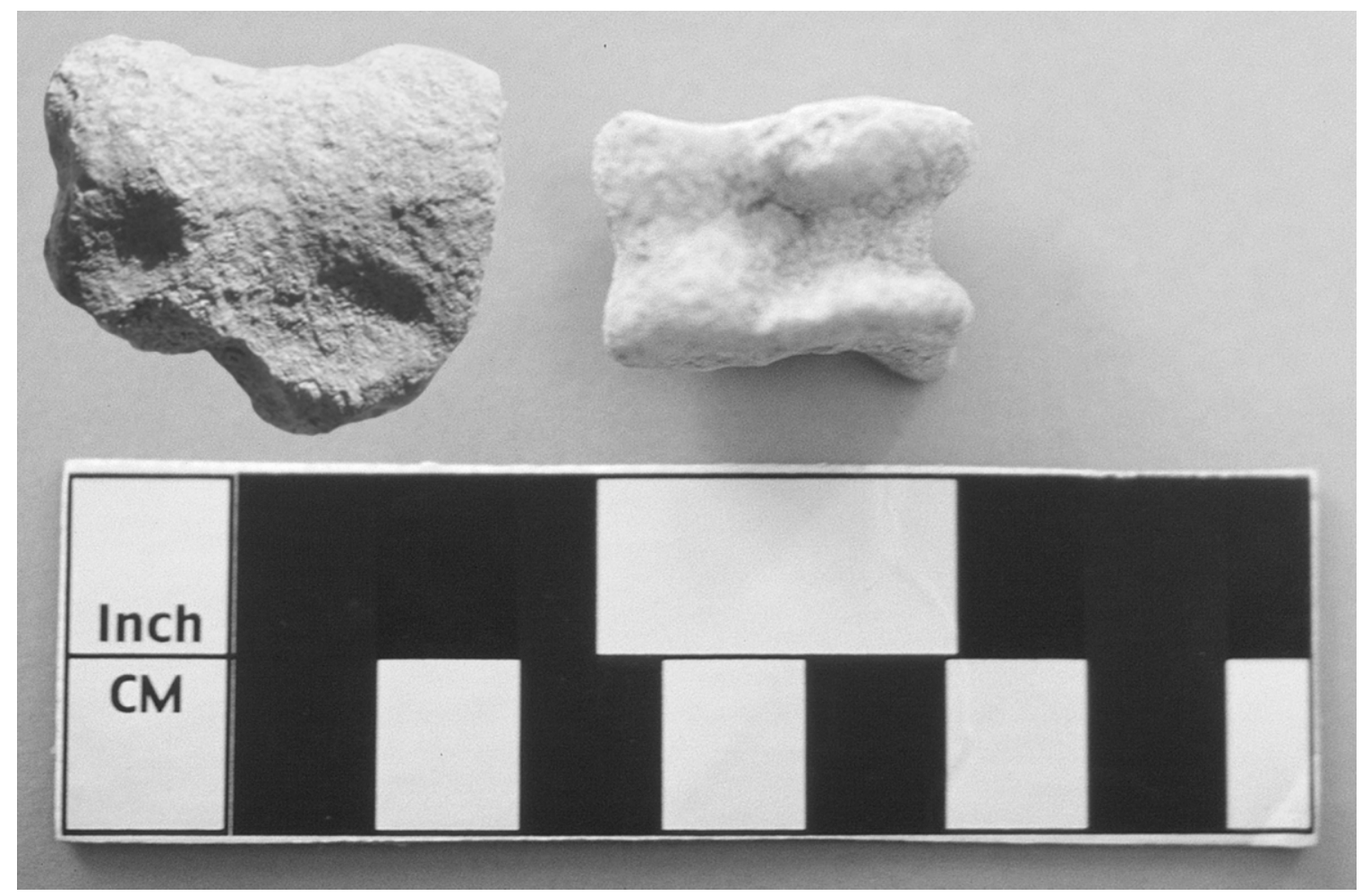

Fig. 3. Dated cow second and third carpal fragment (left) and dated sheep astragalus (right).

out of the Toteng area and allowed occupation by cattle. Although trypanosomiasis is usually fatal to cattle that have been infected, sheep and goats are less likely to die from it (Badenhorst 2002, Connor I 994). Goats and sheep have been observed to live in tsetse-infested areas where cattle cannot survive without the aid of preventative medicine (Connor I994). According to Conner (I994: I88): "Small ruminants have a much shorter generation time than cattle, and it is likely that in tsetse areas this factor has produced greater natural selection for trypanotolerance in these species than has occurred with cattle." If so, increased selection for trypanotolerance for small ruminants may have developed during the long interval between the initial arrival of livestock in East Africa and their spread to the frontier of southern Africa. Therefore it is possible that the herding of sheep spread through the area in advance of cattle. Once sheep had filtered through the area with numerous animal diseases, they could have spread rapidly through the tsetse-free zone to the south, as is suggested by the similarity of the available AMS ages, whereas there appears to have been a delay of several hundred years in the spread of cattle farther to the south.

\section{References Cited}

ANDers Son, C. J. I857. Lake Ngami. London: Dix, Edwards. B ADENHORST, S. 2002. The ethnography, archaeology, rock art, and history of goats (Capra hircus) in southern Africa: An overview. Anthropology of Southern Africa 25 (3\&4):96-I03.

BADENHORST, S., AND I. PLUG. 2003. The archaeozoology of goats, Capra hircus (Linnaeus, 1758): Their size variation during the last two millennia in southern Africa (Mammalia: Artiodacyla: Caprini). Annals of the Transvaal Museum 40: 9I-I II.

в A т thelme, J. W. I985. Fisher-hunters and Neolithic pastoralists in East Turkana, Kenya. (Cambridge Monographs in African Archaeology I3.) British Archaeological Reports International Series 254 .

BLENCH, R. M., AND K. C. MACDONALD. Editors. 2000. The origins and development of African livestock: Archaeology, genetics, linguistics, and ethnography. London: UCL Press.

B OESSNeCK, J., H. H. MÜLleR, AND M. TEICHert. I964. Osteologische Unterscheidungsmerkmale zwischen Schaf (Ovis aries Linné) und Ziege (Capra hircus Linné). Kühn-Archiv 78:I-I29.

C AMPBELL, A. C. 1992. Southern Okavango integrated water development study: Archaeological survey of proposed Maun Reservoir. Gaborone: Department of Water Affairs.

CONNER, R. J. I994. "African animal trypanosomiases," in Infectious diseases of livestock with special reference to southern Africa. Edited by J. A. W. Coetzer, G. R. Thomson, and R. C. Tustin, pp. I67-205. Cape Town: Oxford University Press. DAvies, J. E., AND J. BOWLES. 1976. "Ecology of the tsetse fly in the Okavango Delta," in Proceedings of the Okavango Delta Symposium and its future utilisation. Edited by A. C. Campbell et al., pp. I4I-52. Gaborone: Botswana Society. DEACON, H. J., AND J. DEACON. I999. Human beginnings in South Africa. Walnut Creek, Calif.: AltaMira Press.

DENBOW, J., AND E. WILMSEN. I989. Advent and course of pastoralism in the Kalahari. Science 234:I509-15. 
DIAMOND, J. 2002. Consequences and future of plant and animal domestication. Nature 4I 8:700-707.

EHRET, C. I982. "The first spread of food production to southern Africa: The linguistic evidence," in The archaeological and linguistic reconstruction of African history. Edited by C. Ehret and M. Posnansky. Los Angeles: University of California Press.

E LPH ICK, R. I985. Khoikhoi and the founding of white South Africa. Johannesburg: Raven Press.

GIFFORD-GONZALEZ, D. 2000. Animal disease challenges to the emergence of pastoralism in Sub-Saharan Africa. African Archaeological Review I7:95-I39.

han OtTe, O., D. G. BRADley, J. W. OChieng, y. VERJEE, E. W. HILL, AND J. EDWARD O . REGE. 2002 African pastoralism: Genetic imprints of origins and migrations. Science 296:336-39.

HA U S MAN, A. J . I984. "Holocene human evolution in southern Africa," in From hunters to farmers. Edited by S. A. Brandt and J. D. Clark, pp. 26I-7I. Berkeley: University of California Press.

HENSHILW O OD, C. I996. A revised chronology for pastoralism in southernmost Africa: New evidence of sheep at c. 2000 b.p. from Blombos Cave, South Africa. Antiquity 70:945-49.

HUFFMAN, T. N. I994. Toteng pottery and the origins of Bambata. Southern African Field Archaeology 3:3-9.

LIVINGSTONE, D. I858. Missionary travels and researches in South Africa. New York: Harper.

Mit CHELL, P. 2003. The archaeology of southern Africa. Cambridge: Cambridge University Press.

PLUG, I. I996. "Domestic animals during the Early Iron Age in southern Africa," in Aspects of African archaeology. Edited by G. Pwiti and R. Soper, pp. 5 I5-20. Harare: University of Zimbabwe Publications.

PRUMMEL, W., AND H. J. FRISCH. I986. A guide for the distinction of species, sex, and body size in bones of sheep and goat. Journal of Archaeological Science I3:567-77.

REID, A., K. SADR, AND N. HANSON-JAMES. I 998 . "Herding traditions in Ditswammung," in The archaeology of Botswana. Edited by A. Reid and A. Segobye. Gaborone: Pula Press and the Botswana Society.

robbins, L., M. murphy, G. brook, a. ivester, A. CAMPBELL, R. KLEIN, R. MILO, K. STEWART, W. DOWNEY, AND N. STEVENS. 2000. Archaeology, paleoenvironment, and chronology of the Tsodilo Hills White Paintings Rock Shelter, Northwest Kalahari Desert, Botswana. Journal of Archaeological Science 27:I085-III3.

ROBBins, L., M. MURPHY, A. CAMPBELl, G. BROOK, D. REID, K. HABERYAN, AND W. DOWNeY. I998. Test excavations and reconnaissance palaeoenvironmental work at Toteng, Botswana. South African Archaeological Bulletin 53: I $25-32$.

SADR, K. I998a. The first herders at the Cape of Good Hope. African Archaeological Review i 5: I Io-32.

- I998b. Kalahari archaeology and the Bushman debate. CURRENT ANTHROPOLOGY 38:IO4-I 2 .

SEALY, J., AND R. YATES. I996. Direct radiocarbon dating of early sheep bones: Two further results. South African Archaeological Bulletin 5 г:109-IO.

SHAW, P., M. D. BATEMAN, D. S. G. THOMAS, AND F. D A v i E S. 2003. Holocene fluctuations of Lake Ngami, Middle Kalahari: Chronology and responses to climatic change. Quaternary International i I : $23-35$.

SMITH, A. B. 2005. "The archaeology of hunter/herder interaction in the dry lands of southern Africa," in 23 South: The archaeology and environmental history of the southern deserts. Edited by M. Smith and P. Hesse. Canberra: National Museum of Australia.

SMITH, A. B., AND R. B. LEE. I997. Cho/ana: Archaeological and ethnohistorical evidence for recent hunter-gatherer/ agropastoralist contact in northern Bushmanland, Namibia. South African Archaeological Bulletin 52:52-58.

SOLWAY, J., AND R. LEE. I990. Foragers, genuine or spurious: Situating the Kalahari San in history. CURRENT ANTHROPOLOGY 3I:IO9-46.
WESTPHAL, E. O. J. I963. The linguistic prehistory of Southern Africa: Bush, Kwadi, Hottentot, and Bantu linguistic relationships. Africa 33:237-65.

Wilmsen, E., AND J. DENBow. I990. Paradigmatic history of San-speaking peoples and current attempts at revision. CURRENT ANTHROPOLOGY 3I:489-524.

\section{Ancient DNA, Late Neandertal Survival, and Modern- Human-Neandertal Genetic Admixture ${ }^{1}$}

TIMOTHY D. WEAVER AND CHARLES C. ROSEMAN Department of Human Evolution, Max Planck Institute for Evolutionary Anthropology, Deutscher Platz 6, D-04IO3 Leipzig, Germany (weaver@eva.mpg.de)/Department of Anthropological Sciences, Stanford University, 450 Serra Mall, Building 360, Stanford, CA 94305-2II7, U.S.A. (croseman@stanford.edu).3 II 05

[Supplementary material appears in the electronic edition of this issue on the journal's web page (http://www.journals.uchicago. edu/CA/home.html).]

One of the longest-standing questions in paleoanthropology is the place of Neandertals in human evolution. The fate of Neandertals is often framed in terms of polarized replacement and multiregional models. In reality, most anthropological geneticists, human paleontologists, and Paleolithic archaeologists now favor a predominantly extra-European origin for the earliest modern human populations in Europe (e.g., Bräuer 200I, Conard and Bolus 2003, d'Errico 2003, Eswaran 2002, Klein 2003, Pääbo 2003, Relethford 200I $b$, Stringer 2003, Templeton 2002, Trinkaus et al. 2003, Underhill et al. 200I, Zilhão and d'Errico I999, but see Wolpoff 2002). Intense debate, however, continues about the nature and timing of the interactions between ancient modern humans and Neandertals, with particular emphasis on the degree to which Neandertals contributed genetically to the earliest modern human populations in Europe.

Analyses of mitochondrial (mt) DNA extracted from multiple Neandertal fossils have confirmed abundant skeletal evidence that Neandertals were biologically dis-

(C) 2005 by The Wenner-Gren Foundation for Anthropological Research. All rights reserved oOI I-3204/2005/4604-00 I \$ I0.00

I. We thank Uma RamaKrishnan for help with SIMCOAI, Erik Trinkaus and João Zilhão for useful discussions, and Richard Klein, Alec Knight, and Teresa Steele for valuable comments on earlier drafts of this paper. 
tinct (i.e., formed reciprocally monophyletic groups) from living and Holocene (recent) humans and at least some more ancient modern humans (Knight 2003, Schmitz et al. 2002, Serre et al. 2004). The distinctiveness of Neandertal mtDNA shows that either modern human and Neandertal populations diverged deep in the past or human mtDNA diversity was much greater and more subdivided in the past than in the present. A single randomly mating population of modern humans and Neandertals is not consistent with the mtDNA evidence (Nordborg 1998). It would also appear that comparisons of living human and ancient Neandertal mtDNA could determine the extent of the genetic contribution of Neandertals to the earliest modern human populations in Europe, but on the basis of these data alone it is difficult to rule out many scenarios involving extensive admixture. Because Neandertal mtDNA lineages, along with many ancient modern human lineages, could have been lost through random genetic drift in populations ancestral to living humans, the further extraction of Neandertal mtDNA is unlikely to resolve this issue (Nordborg 1998, Relethford 200Ia) (fig. I). If ever technically feasible, the extraction of Neandertal nuclear DNA is unlikely to resolve this issue either. Even if Neandertals were a separate evolutionary lineage for hundreds of thousands of years, we would still not expect their nuclear DNA sequences to form separate clades from those of living humans (Pääbo 2003), although the Y-chromosome or autosomal microsatellites could provide additional insight. Extensive studies of the genetic variation in living humans at tens to hundreds of unlinked autosomal loci may eventually help determine the extent of the genetic contribution of Neandertals to early modern human populations (for further discussion see Nordborg 2000, Wall 2000). These studies, unlike those based on ancient DNA, where Neandertal sequences are known, will always have to rely on assumptions about the timing and degree of genetic divergence of modern human and Neandertal lineages.

The amount of information preserved in living humans about the genetics of the ancient modern human population - and thus admixture between ancient modern humans and Neandertals-is strongly dependent on demographic history and population structure. Under certain demographic scenarios, the distinctiveness of Neandertal mtDNA is very useful for assessing the extent of admixture between ancient modern humans and Neandertals; under other scenarios it is not. In this context, we investigated whether the redating of a number Neandertal fossils to about 30,000 years ago (Hublin et al. I995, Mellars 1998, Ovchinnikov et al. 2000, Smith et al. I999) and hence the possibility of a late survival of Neandertals in Europe bear significantly on the likelihood that Neandertals contributed genetically to early modern human populations. ${ }^{2}$

2. The direct radiocarbon dating of modern human skeletal remains from sites such as Vogelherd in Germany (Conard, Grootes, and Smith 2004) and Velika Pečina in Croatia (Smith et al. I999) to the Holocene does not eliminate the possibility of a period of overlap

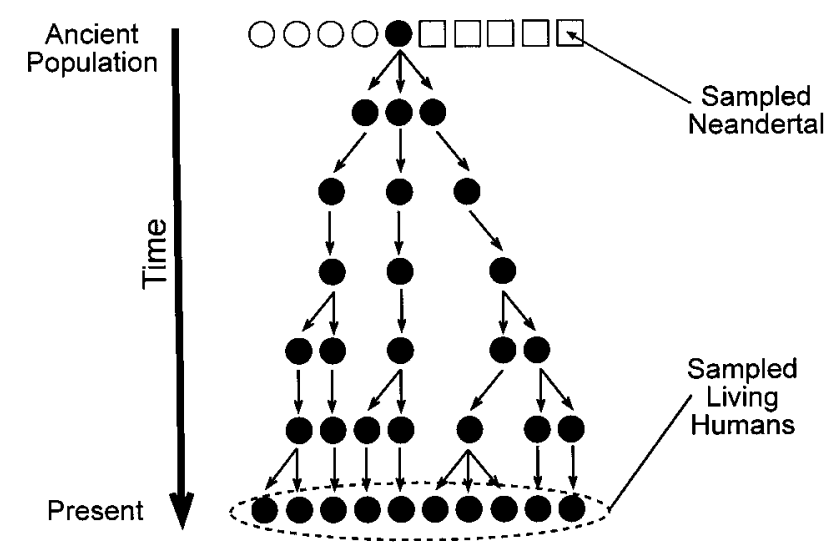

Fig. I. Ancient population genetics. Although the Neandertals sample the ancient population, the living humans sample the present population. Because mtDNA lineages will be lost over time through random genetic drift, a sample from the present translates into a smaller sample of the ancient population. This makes it possible for Neandertal mtDNA lineages to have made up a large proportion of the ancient population (in this diagram 50\%) but by chance not be detectable in a sample of living humans.

Previous work using similar methods has tended to address fairly general scenarios (Manderscheid and Rogers 1996; Nordborg 1998, 2000; Serre et al. 2004; Wall 2000). Here we wanted to address the implications for the likelihood of modern-human-Neandertal admixture of two specific scenarios that have been proposed in the paleoanthropological literature. In so doing, we also explicitly modeled a contact period between ancient modern humans and Neandertals, which had not been done previously. In short, we asked, if ancient modern humans and Neandertals overlapped for many thousands of years in Europe, is it likely that there could have been both substantial admixture between ancient modern humans and Neandertals and the complete loss of Neandertal mtDNA lineages in living humans?

We used computer simulations to contrast a scenario of late Neandertal survival (I0,000 years of contact between Neandertals and ancient modern humans from

between Neandertals and ancient modern humans in Europe, because there are other modern human specimens from the Pestera cu Oase in Romania (Trinkaus et al. 2003) and Kent's Cavern in England (Hedges et al. I989) that are directly radiocarbon-dated to approximately 35,000 and 31 , 000 years ago respectively. Additionally, stratigraphic associations suggest that modern human specimens from sites such as Mladec in the Czech Republic (Svoboda, van der Plicht, and Kuzelka 2002), Kostenki in Russia (Hoffecker 2002), and a number of sites in France (Gambier I989) are of similar age, although all of these associations warrant further evaluation. A potentially more serious problem for the late-survival scenario is that there are few dates supporting the survival of Neandertals to approximately 30,000 years ago, leaving open the possibility of errors in dating due to undetectable contamination from minute amounts of recent carbon (Klein 2003, Zilhão and d'Errico I999). 
A.

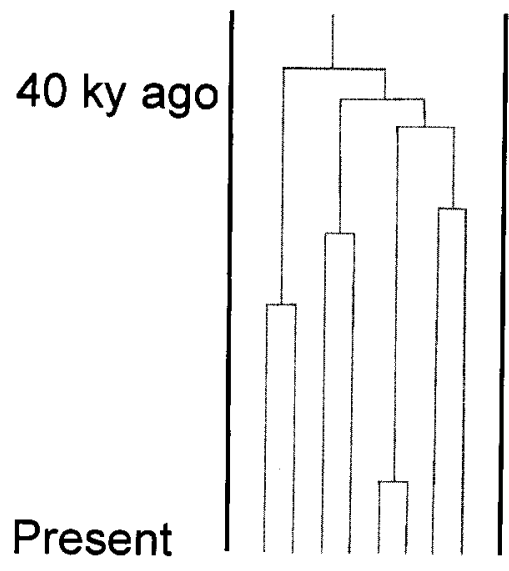

B.

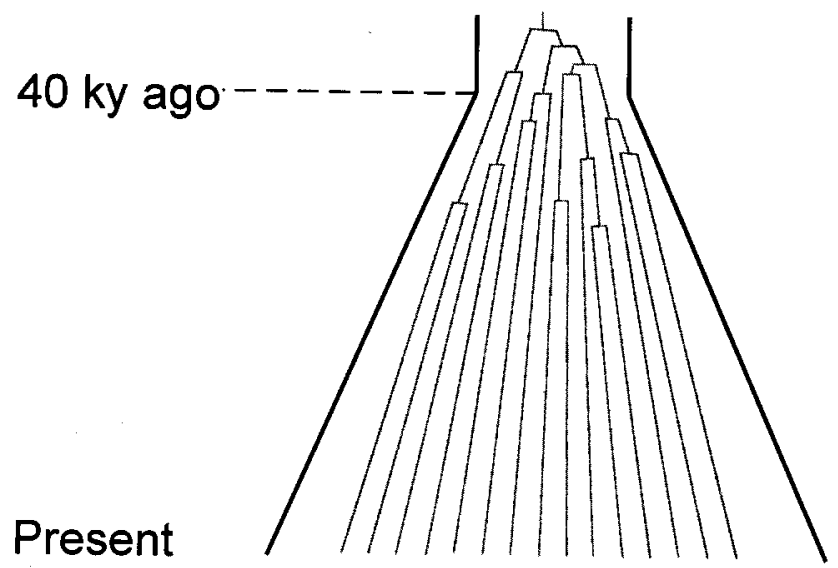

Fig. 2. Basic demographic models. A, constant population size. Effective population size (for females) was I, 875 , and expected coalescence time was $\sim 75,000$ years ago. B, rapid population growth. Pregrowth effective population size was I,000. Growth started at 40,000 years ago and ended with a present-day effective population size of $10^{8}$, and expected coalescence time was $\sim 75,000$ years ago.

40,000 to 30,000 years ago/ with a scenario of rapid Neandertal disappearance (only one generation of contact at 40,000 years ago) under two basic demographic models: constant population size and constant population size followed by rapid population growth (fig. 2 and particularly fig. 3). We calculated two measures of Neandertal admixture under the two different scenarios and the two basic demographic models: total Neandertal admixture and per generation Neandertal contribution. Total admixture is the maximum fraction $(p<0.05)$ of the modern human population at the end of the period of admixture that could have been Neandertal mtDNA lineages, given that we do not find Neandertal lineages in living humans (the total accumulated Neandertal admixture that would have been possible). The per generation contribution is the maximum fraction $(p<0.05)$ of the modern human population that could have come from Neandertal migrants each generation. This is the maximum possible Neandertal migration rate. [For details of our methods, see the electronic edition of this issue on the journal's web site.]

\section{RESULTS}

Under the rapid-disappearance scenario (fig. 3,a), Neandertals could have contributed substantially to the modern human population for models of constant population size and rapid population growth (table I). Under the latesurvival scenario (fig. $3, b$ ), the per generation Neandertal contribution $(m)$ could only have been low for both the constant-size and growth models, but for the constantsize model the total Neandertal admixture $(c)$ could still have been high (table I). For the late-survival scenario and the growth model, the total Neandertal admixture (c) could only have been extremely low (table I). Where comparable, these results are consistent with those of others (Manderscheid and Rogers I996; Nordborg I998, 2000; Serre et al. 2004; Wall 2000).

Simulations of intermediate scenarios are more dependent on the specific parameters of the demographic models, such as the effective population sizes and the exponential population growth constant, but some qualitative observations are possible. For the growth model, the relationship between the total amount of Neandertal admixture and time is nonlinear, and therefore changing the contact period in the late-survival scenario from I0,000 to 8,000 years does not drastically change estimates of total Neandertal admixture, but changing the rapid-disappearance scenario from one generation to 2,000 years significantly reduces the amount of total Neandertal admixture that could have occurred. Thus, the late-survival period need not have been as long as Io,ooo years for the total amount of Neandertal admixture that could have occurred to be low. For the constantsize model, the relationship between the total amount of Neandertal admixture and time is approximately linear.

\section{DISCUSSION}

Is Neandertal mtDNA actually so distinctive? One basic assumption of our simulations is that Neandertal mtDNA lineages are distinct relative to the variation found in living humans. The initial studies by the Neandertal mtDNA sequencing groups found that living human and Neandertal sequences differed substantially from each other (Krings et al. I997, 2000; Ovchinnikov 
et al. 2000; Schmitz et al. 2002). A reanalysis by Gutiérrez, Sánchez, and Marín (2002) did conclude that Neandertal mtDNA was within the range of living human variation, but this result may have been an artifact of bootstrapping sequences to generate neighbor-joining trees with a rapidly evolving genetic system such as mtDNA, in which the ratio of noisy (i.e., highly inconsistent or homoplastic) to stable sites is high. This approach may create many neighbor-joining trees whose topology is determined primarily by inconsistent sites, so by chance some living humans and Neandertals sometimes group together to the exclusion of other living humans (A. Knight, personal communication). In contrast, Caramelli et al. (2003) found no overlap between modern human and Neandertal mtDNA sequences using multidimensional scaling, and along with living human sequences this analysis included possible (because contamination cannot be ruled out) ancient modern human sequences from Paglicci I 2 and 25, Italy (PI2 and $\mathrm{P}_{25}$ ), and Lake Mungo 3, Australia (LM3). Knight (2003) used a phylogenetic approach to Neandertal mtDNA and found four highly consistent synapomorphies that unite Neandertals to the exclusion of all living humans and four highly consistent synapomorphies that unite all living humans to the exclusion of Neandertals (a total of eight highly consistent sites that define the two clades, including an insertion, which is a very rare event). These eight sites are consistent across thousands of living humans and are known to have low mutation rates. Additionally, for preserved sites, the mtDNA sequences from $\mathrm{P}_{12}$ and $\mathrm{P}_{25}, \mathrm{LM}_{3}$, and the nuclear mitochondrial insert (thought to have diverged shortly before the oldest coalescence of living human mtDNA sequences [Zischler et al. I995]) have none of the Neandertal synapomorphies while possessing all of the diagnostic derived sites of living human sequences (A. Knight, personal communication). Recently, mtDNA fragments were ex-
TABLE I

Maximum Neandertal Contribution to the Modern Human Population

Rapid Disappearance Late Survival

$$
\begin{aligned}
& \text { Constant population size } \\
& \quad m \\
& \quad c \\
& \text { Population growth } \\
& m
\end{aligned}
$$$$
\text { c }
$$$$
0.738(73.8 \%)
$$$$
0.002(0.2 \%)
$$$$
0.655(65.5 \%)
$$$$
0.243(24.3 \%)
$$$$
\sim 0(\sim 0 \%)
$$$$
0.243(24.3 \%)
$$$$
\sim 0(\sim 0 \%)
$$

NOTE: The significance level is $5 \% ; m$ is the per generation Neandertal contribution or the migration rate; $c$ is the total Neandertal admixture; results are for simulations where the number of present-day lineages sampled was Ioo, except for the late-survival scenario with population growth, where the results are heavily dependent on the number of present-day lineages sampled and therefore $m$ and $c$ decrease rapidly toward zero with more sampled lineages.

tracted from four additional Neandertal and five early modern human fossils that had similar biomolecular preservation. All the Neandertals and none of the ancient modern humans yielded sequences similar to previous Neandertal sequences (Cooper, Drummond, and Willerslev 2004, Serre et al. 2004). It appears, therefore, that the assumption that Neandertal mtDNA is distinct from that of living humans is reasonable.

Is there genetic evidence for human population growth about 40,000 years ago? Our simulations assumed either constant population size or constant size followed by rapid population growth, starting at 40,000 years ago. Which demographic model is more plausible? The human population has certainly grown over time, but there is uncertainty about when and how rapidly this growth occurred. The patterning of living human
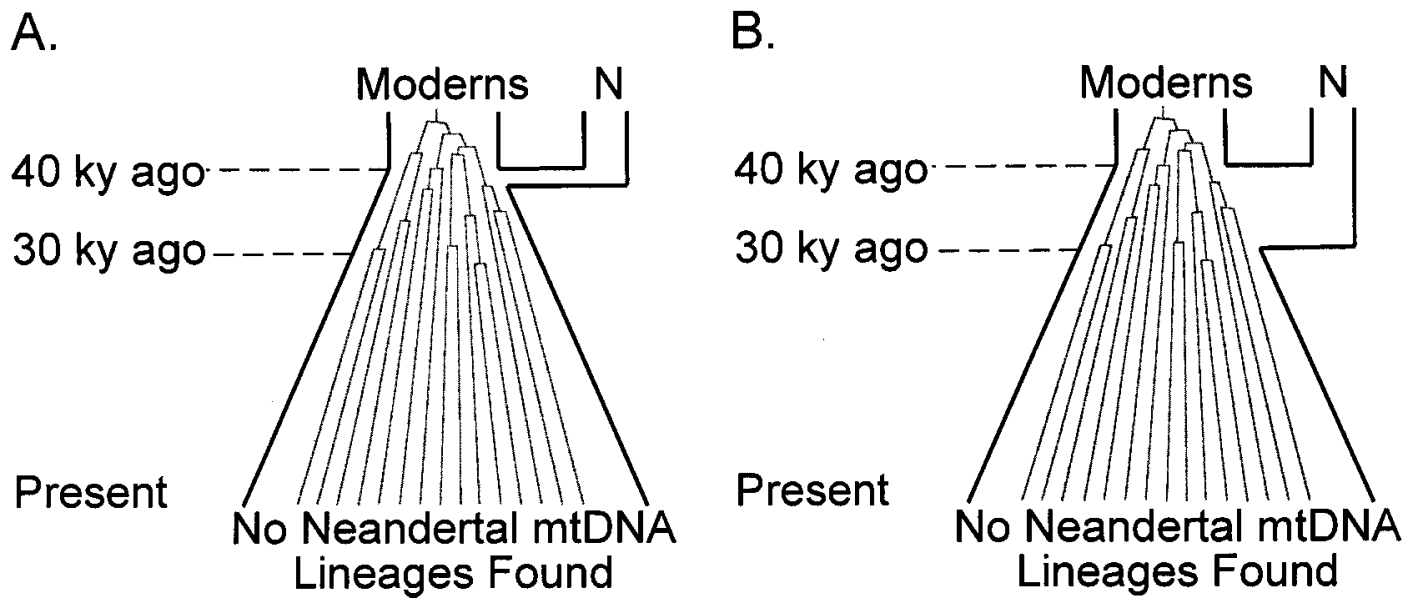

Fig. 3. Scenarios under the growth model. A, rapid disappearance, with Neandertals contributing to the modern human population for only one generation at 40,000 years ago. B, late survival, with Neandertals contributing for Io,000 years, starting 40,000 years ago (diagrams modified from Serre et al. [2004]: fig. 4). 
mtDNA variation appears to show the signature of rapid population growth from a small size starting 200,000-40,000 years ago (Excoffier 2002, Excoffier and Schneider I999, Harpending et al. I998, Ingman et al. 2000). Global samples and most individual populations show a signature of growth. However, this pattern could be the result of a recent selective sweep rather than population growth (Hawks et al. 2000, Hawks and Wolpoff 200I, Hey 1997, Wise, Sraml, and Easteal I998). It is difficult to distinguish a selective sweep from population growth. Both result in an excess of rare alleles relative to what we would expect under neutral evolution in a population that has been constant in size (Harpending and Rogers 2000). The best way to distinguish between a selective sweep and population growth is to examine multiple genetic loci. The effects of selection should be observable only in regions tightly linked to the loci conferring a selective advantage to the organism, while demographic events should impact all loci uniformly. We review four relevant categories of genetic data: autosomal and X-chromosome single-nucleotide polymorphisms (SNPs), autosomal and X-chromosome microsatellites, Y-chromosome SNPs, and Y-chromosome microsatellites.

Many studies of autosomal and X-chromosome SNPs have provided only limited support for the signature of rapid population growth found in mtDNA. In a fairly comprehensive review, Ptak and Przeworski (2002) compiled a large database of existing studies of more than 400 regions of the human genome and found only weak support for a model of population growth. In this database, the average value for Tajima's $\mathrm{D}(D)$ was negative, which could be taken as evidence for population growth, but, as Ptak and Przeworski show statistically, negative $D$ values more likely result from the pooling of individuals from genetically subdivided populations. Because many SNPs are specific to certain populations (Stephens et al. 200I), the number of rare alleles increases and $D$ decreases when subdivided populations are pooled.

However, ascertainment bias is another important confounding factor. SNPs or any molecular data are useful for estimating demographic history only if ascertainment bias can be modeled or controlled so that the complete pattern of polymorphism at a particular locus can be inferred (Eller 200I, Polanski and Kimmel 2003, Wakeley et al. 200I). Ascertained markers are polymorphic loci detected using a small set of individuals. Polymorphic loci detected in the small set are then typed in a larger study sample to examine the relationships between alleles at these loci and geography and phenotypic variation. Ascertainment bias occurs when SNPs are located using small or unrepresentative samples or when certain SNPs are excluded on the basis of levels or patterns of polymorphism. Sometimes exclusion is implicit, such as eliminating some SNPs because they might be sequencing errors. Polanski and Kimmel (2003) found that estimates of population growth are extremely sensitive to ascertainment bias because it preferentially excludes rare SNPs from an analysis. The exclusion of rare SNPs will make many SNPs in the sample appear to be at intermediate frequencies, which would be interpreted as evidence of constant population size or a population crash.

In a recent study of SNPs at $>20,000$ genomewide loci from known populations, Marth et al. (2004) explicitly modeled and corrected for ascertainment bias and controlled for population structure, at least to a certain extent, by examining African-American, East Asian, and European-American samples separately. They concluded that all samples showed signatures of population growth consistent with the results for mtDNA. The East Asian and European-American diversity fit a model of a bottleneck followed by growth while the African-American sample fit a model of growth alone. Marth et al. estimated that post-bottleneck growth began $84,000-60,000$ years ago for the East Asian sample and 86,000-54,000 years ago for the European-American sample, which overlaps the 200,000-40,000 years ago range for mtDNA. They estimated that growth in the African-American sample started earlier.

In general, autosomal and X-chromosome microsatellites tend to show evidence for rapid population growth, with expansion dates that are roughly concordant with those for mtDNA (reviewed by Rogers 200I). Pooling of subdivided populations should be less of a problem than for SNPs because most microsatellite variants are found in multiple populations (Rosenberg et al. 2002). Ascertainment bias should also be less of a problem than for SNPs. Microsatellites have high mutation rates, which means that polymorphisms will be detected even in small ascertainment samples (Eller 200I). In the most extensive study to date, Zhivotovsky, Rosenberg, and Feldman (2003) analyzed the variation at 377 autosomal microsatellite loci from 52 globally distributed populations. Statistics of population growth were calculated for 27I of the loci for each individual population. Most populations show strong signatures of population growth with estimated start times that are consistent with those for mtDNA.

Results from the $\mathrm{Y}$ chromosome regarding past population growth are equivocal. Initial studies of Y-chromosome SNPs (e.g., Thomson et al. 2000) tended to show evidence for population growth. However, these studies were conducted on global samples pooled across subdivided populations, so the results could be due to population subdivision rather than growth (Ptak and Przeworski 2002). More recent studies of SNPs that pooled only European and Mediterranean populations (Pereira et al. 200I) or examined individual populations (Hammer et al. 2003) have found little evidence for growth. However, as for autosomal and X-chromosome SNPs, ascertainment bias may be a problem. An analysis of eight Ychromosome microsatellites from 50 globally distributed populations showed strong evidence of population growth (Pritchard et al. I 999), but the number of loci was small, the effects of subdivision were not accounted for, and the dates for the start of growth are more recent than for mtDNA.

We believe that the close correspondence between studies of mtDNA and microsatellites and recent studies 
of autosomal and X-chromosome SNPs that controlled for ascertainment bias and population subdivision makes it reasonable to assume a model of rapid human population growth from a small size, starting $200,000-40,000$ years ago. For the selective-sweep alternative to be correct there would have to have been virtually simultaneous selective sweeps in hundreds of unlinked genetic regions, which seems unlikely (Excoffier 2002, Relethford 200I $b$, Rogers 200I). Additionally, a signature of population growth may have been obscured in some loci by other factors such as balancing selection (Harpending and Rogers 2000, Rogers 200I). Nevertheless, it is clear that more research needs to be done to resolve this issue.

\section{CONCLUSIONS}

The significance of ancient Neandertal mtDNA for resolving the fate of Neandertals increases greatly when considered in light of models for modern human origins derived from archaeology. On the basis of mtDNA, if Neandertals survived late in Europe, their per generation contribution to early modern human populations must have been fairly small $(<0.2 \%)$ or we would find Neandertal mtDNA lineages in living humans. If the human population size remained constant and small until very recently, then the total, accumulated Neandertal admixture could still have been large, but if the human population started to grow rapidly from a small size about 40,000 years ago, then even a very small Neandertal genetic contribution to modern human populations can be ruled out. Archaeology tends to support the rapid population growth model (Klein et al. 2004, Stiner et al. I999), as does living human mtDNA (Excoffier and Schneider I999, Ingman et al. 2000). Other genetic regions are more equivocal about the timing and magnitude of population growth (Harpending and Rogers 2000, Ptak and Przeworski 2002, Wall and Przeworski 2000), but recent studies of SNPs and microsatellites appear to be reaching a consensus consistent with the results for mtDNA (Marth et al. 2004, Zhivotovsky, Rosenberg, and Feldman 2003). Our results stress the importance of fully integrating archaeological, fossil, and genetic evidence in investigations of modern human origins.

\section{References Cited}

B R ̈̈UER, G. 200I. "The 'out-of-Africa' model and questions of regional continuity," in Humanity from African naissance to coming millennia. Edited by P. V. Tobias, M. A. Raath, J. Moggi-Cecchi, and G. Doyle, pp. I83-89. Florence: Firenze University Press.

CARAmelli, D., C. Lalueza-fox, C. Vernesi, M. LARI, A. CASOLI, F. MALLEGNI, B. CHIARELLI, I. DUPANLOUP, J. BERTRANPETIT, G. BARBUJANI, AND G. BERTORELLE. 2003. Evidence for a genetic discontinuity between Neandertals and 24,000-year-old anatomically modern Europeans. Proceedings of the National Academy of Sciences, U.S.A. I00:6593-97.

CONARD, N. J., AND M. BOLUS. 2003. Radiocarbon dating the appearance of modern humans and timing cultural innova- tions in Europe: New results and new challenges. Journal of Human Evolution 44:33 I-7 I.

CONARD, N. J., P. M. GROOTES, AND F. H. SMITH. 2004. Unexpectedly recent dates for human remains from Vogelherd. Nature 430:198-201.

COOPER, A., A. J. DRUMMOND, AND E. WILleRSLeV. 2004. Ancient DNA: Would the real Neandertal please stand up? Current Biology I4:R43 I-33.

D'ERRICO, F. 2003. The invisible frontier: A multiple species model for the origin of behavioral modernity. Evolutionary Anthropology I 2: I 88-202.

ELLER, E. 200I. Estimating relative population sizes from simulated data sets and the question of greater African effective size. American Journal of Physical Anthropology I66:I-I 2.

ESW ARA N, V. 2002. A diffusion wave out of Africa: The mechanism of the modern human revolution. CURRENT ANTHROPOLOGY 43:749-74.

EXCOFFIER, L. 2002. Human demographic history: Refining the recent African origin model. Current Opinion in Genetics and Development I 2:675-82.

EXCOFfier, L., AND S. SCHNeIDER. I999. Why huntergatherer populations do not show signs of Pleistocene demographic expansions. Proceedings of the National Academy of Sciences, U.S.A. 96:10597-602.

GAMBIER, D. I989. "Fossil hominids from the early Upper Palaeolithic (Aurignacian) of France," in The human revolution.

Edited by P. Mellars and C. B. Stringer, pp. I94-2 I I. Edinburgh: Edinburgh University Press.

gutírrez, G., D. SÁncheZ, AND A. MArín. 2002. A reanalysis of the ancient mitochondrial DNA sequences recovered from Neandertal bones. Molecular Biology and Evolution I9:I359-66.

HAMMER, M. F., F. BLACKMER, D. GARRIGAN, M. W. NACHMAN, AND J. WILDER. 2003. Human population structure and its effects on sampling Y chromosome sequence variation. Genetics I64:I495-I 509.

HARPENDING, H. C., M. A. BAtZer, M. GuRVen, L. B. JORDE, A. R. ROGERS, AND S. T. SHERRY. I 998. Genetic traces of ancient demography. Proceedings of the National Academy of Sciences, U.S.A. 95:196I-67.

HARPENDING, H. C., AND A. R. ROGERS. 2000. Genetic perspectives on human origins and differentiation. Annual Review of Genomics and Human Genetics I:36I-85.

HAWKS, J., K. HUNLEY, S.-H. LEE, AND M. H. WOLPOFF. 2000. Population bottlenecks and Pleistocene human evolution. Molecular Biology and Evolution 17:2-22.

HAWKS, J., AND M. H. WOLPOFF. 20OI. Brief communication: Paleoanthropology and the population genetics of ancient genes. American Journal of Physical Anthropology I I4:269-72.

HedGes, R. E. M., R. A. HOUSley, I. A. LAW, AND C. R. B R O N K. I989. Radiocarbon dates from the Oxford AMS system: Archaeometry datelist 9. Archaeometry 31:207-34.

HEY, J. I997. Mitochondrial and nuclear genes present conflicting portraits of human origins. Molecular Biology and Evolution I4:I66-72.

H OFF С K E R, J. F. 2002. Desolate landscapes: Ice-age settlement in eastern Europe. New Brunswick: Rutgers University Press.

HUBlin, J.-J., C. BARROSO RUIZ, P. MEDINA LARA, M. FONTUGNe, AND J.-L. ReYSS. I995. The Mousterian site of Zafarraya (Andalucia, Spain): Dating and implications on the Palaeolithic peopling processes of Western Europe. Comptes Rendus de l'Académie des Sciences, Paris $32 \mathrm{I}$ : 93I-37.

INGMAN, M., H. KAESSMANN, S. PÄ̈̈вO, AND U. GYLLENSTEN. 2000. Mitochondrial genome variation and the origin of modern humans. Nature 408:708-I3.

KLEIN, R. G. 2003. Whither the Neanderthals? Science 299: I 525-27.

KLein, R. G., G. AVery, K. Cruz-Uribe, D. halkett, J. E. PARKINGTON, T. STEELE, T. P. VOLMAN, AND R. YA TE S. 2004. The Ysterfontein I Middle Stone Age site, South Africa, and early human exploitation of coastal re- 
sources. Proceedings of the National Academy of Sciences, U.S.A. I0I:5708-I 5 .

KNIGHT, A. 2003. The phylogenetic relationship of Neandertal and modern human mitochondrial DNAs based on informative nucleotide sites. Journal of Human Evolution 44:627-32.

KRINGS, M., C. CAPELli, F. TSCHeNTSCHER, H. GeISERT, S. MEYER, A. VON HAESELER, K. GROSSSCHMIDT, G. POSSNERT, M. PAUNOVIC, AND S Р ̈̈ в о. 2000. A view of Neandertal genetic diversity. NatureGenetics 26:144-46.

KRINGS, M., A. STONE, R. W. SCHMITZ, H. KRAINIT ZKI, M. STONEKING, AND S. P ̈̈̈̈вO. I997. Neandertal DNA sequences and the origin of modern humans. Cell 90: I9-30.

MANDERSCHEID, E. J., AND A. R. ROGERS. I996. Genetic admixture in the Late Pleistocene. American Journal of Physical Anthropology IOо:I-5.

MARTH, G. T., E. CZABARKA, J. MURVAI, AND S. T. SHERRY. 2004. The allele frequency spectrum in genome-wide human variation data reveals signals of differential demographic history in three large world populations. Genetics I66: 35 I -72 .

MELLARS, P. I998. The fate of the Neanderthals. Nature 395: $539-40$.

N O RD B ORG, M. I998. On the probability of Neanderthal ancestry. American Journal of Human Genetics 63:1237-40.

. 2000. "On detecting ancient admixture," in Genes, fossils, and behaviour: An integrated approach to human evolution. (NATO Science Series: Life Sciences, 3 Io.) Edited by P. Donnelly, pp. I23-36. Amsterdam: IOS Press.

OVCHINNIKOV, I. V., A. G ÖTHERSTRÖM, G. P. ROMA NOVA, V. M. KHARITONOV, K. LIDÉN, AND W. GOODWIN. 2000. Molecular analysis of Neanderthal DNA from the northern Caucasus. Nature 404:490-93.

Р $\ddot{A}$ в O, S. 2003. The mosaic that is our genome. Nature 42: 409-I2.

PEReIRA, L., I. DUPANloup, Z. H. ROSSER, M. A. JOBLING, AND G. BARBUJANI. 200I. Y-chromosome mismatch distributions in Europe. Molecular Biology and Evolution I 8:I259-7I.

POLANSKI, A., AND M. KIMMEL. 2003. New explicit expressions for relative frequencies of single-nucleotide polymorphisms with application to statistical inference on population growth. Genetics I 65:427-36.

PRITCHARD, J. K., M. T. SEIELSTAD, A. PEREZ-LEZAUN, AND M. W. FELDMAN. I999. Population growth of human Y chromosomes: A study of Y chromosome microsatellites. Molecular Biology and Evolution I6:1791-98.

PTAK, S. E., AND M. PRZEWORSKI. 2002. Evidence for population growth in humans is confounded by fine-scale population structure. Trends in Genetics I 8:559-63.

RELETHFORD, J. H. $200 I a$. Ancient DNA and the origin of modern humans. Proceedings of the National Academy of Sciences, U.S.A. 98:390-9I.

- 200I b. Genetics and the search for modern human origins. New York: Wiley-Liss.

ROGERS, A. R. 200I. Order emerging from chaos in human evolutionary genetics. Proceedings of the National Academy of Sciences, U.S.A. 98:779-80.

ROSENBERG, N. A., J. K. PRitchard, J. L. Weber, h. M. CANN, K. K. KIDD, L. A. ZHIVOTOVSKY, AND M. W. FELDMAN . 2002. Genetic structure of human populations. Science 298:238I-85.

SCHMITZ, R. W., D. SERRE, G. BONANI, S. FEINE, F. HILLGRUBER, H. KRAINITZKI, S. PÄÄBO, AND F. H. SMITH. 2002. The Neandertal type site revisited: Interdisciplinary investigations of skeletal remains from the Neander Valley, Germany. Proceedings of the National Academy of Sciences, U.S.A. 99:13342-47.

SERRE, D., A. LANGANeY, M. CheCh, M. TESCHLERNICOLA, M. PAUNOVIC, P. MENNECIER, M. HOFReI-
TER, G. POSSNERT, AND S. PÄ̈̈во. 2004. No evidence of Neandertal mtDNA contribution to early modern humans. Public Library of Science Biology 2:03 I3-17.

SMith, F. H., E. TRINKAUS, P. B. Pettitt, i. KARAVANIC, AND M. PAUNOVIC. I999. Direct radiocarbon dates for Vindija GI and Velika Pecina Late Pleistocene hominid remains. Proceedings of the National Academy of Sciences, U.S.A. 96:1 228 I-86.

Stephens, J. C., J. A. SCHneider, D. A. TANGUAy, J. CHOI, T. ACHARYA, S. E. STANLEY, R. JIANG, C. J. MESSER, A. CHEW, J.-H. HAN, J. DUAN, J. L. CARR, M. S. LEe, B. KOSHY, A. M. KUMAR, G. ZHANG, W. R. NEWELL, A. WINDEMUTH, C. XU, T. S. KALBFLEISCH, S. L. SHANER, K. ARNOLD, V. SCHULZ, C. M. DRYSDALE, K. NANDABALAN, R. S. JUDSON, G. RUANO, AND G. F. VOVIS. 200I. Haplotype variation and linkage disequilibrium in 313 human genes. Science 293; 489-93.

Stiner, M. C., N. D. MUnRo, T. A. Surovell, e. TCHERNOV, AND O. BAR-YOSEF. I999. Paleolithic population growth pulses evidenced by small animal exploitation. Science 283:190-94.

STR INGER， C. B. 2003. Out of Ethiopia. Nature 423:692-95. SVOBODA, J., J. VAN DER PLICHT, AND V. KUZELKA. 2002. Upper Paleolithic and Mesolithic human fossils from Moravia and Bohemia (Czech Republic): Some new ${ }^{14} \mathrm{C}$ dates. Antiquity 76:957-62.

TEMPLET ON, A. R. 2002. Out of Africa again and again. $\mathrm{Na}$ ture 4I6:45-5 I.

THOMSON, R., J. K. PRITCHARD, P. Shen, P. J. OefNER, AND M. W. FELDMAN. 2000. Recent common ancestry of human Y chromosomes: Evidence from DNA sequence data. Proceedings of the National Academy of Sciences, U.S.A. 97:7360-65.

TRINKAUS, E., O. MOLdovan, S. Milota, A. BILGAR, L. SARCINA, S. ATHREYA, S. E. BAILEY, R. ROD RIGO, G. MIRCEA, T. HIGHAM, C. B. RAMSEY, AND J. VAN DER PLICHT. 2003. An early modern human from the Pestera cu Oase, Romania. Proceedings of the National Academy of Sciences, U.S.A. IOO:I I23 I-36.

UNDERHILL, P. A., G. PASSARINO, A. A. LIN, P. SHEN, M. M. LAHR, R. A. FOLEY, P. J. OEFNER, AND L. L. CAVALLI-SFORZA. 200I. The phylogeography of Y chromosome binary halotypes and the origins of modern human populations. Annals of Human Genetics 65:43-62.

WAKeley, J., R. Nielsen, S. N. LUi-CORDero, AND K. ARDLIE. 20OI. The discovery of single-nucleotide polymorphisms-and inferences about human demographic history. American Journal of Human Genetics 69:1332-47.

WALL, J. D. 2000. Detecting ancient admixture using sequence polymorphism data. Genetics I 54:I27 I-79.

WALL, J., AND M. PRZEWORSKI. 2000. When did the human population size start increasing? Genetics I 55:1865-74.

Wise, C. A., M. SRAML, AND S. easteal. I998. Departure from neutrality at the mitochondrial NADH dehydrogenase subunit 2 gene in humans, but not in chimpanzees. Genetics I48:409-2 I.

W OLP OFF, M. H. 2002. Comment on: A diffusion wave out of Africa: The mechanism of the modern human revolution, by V. Eswaran. CURRENT ANTHROPOLOGY 43:768-69.

Zhivotoviky, L. A., N. A. ROSENBERG, AND M. W. FELDMAN . 2003. Features of evolution and expansion of modern humans, inferred from genomewide microsatellite markers. American Journal of Human Genetics 72:1 I 7 I-86.

ZILH Ã O, J., AND F. D'ERRIC O. I999. The chronology and taphonomy of the earliest Aurignacian and its implications for the understanding of Neandertal extinction. Journal of World Prehistory I3:I-68.

Zischler, H., H. Geisert, A. Von haEseler, AND S. Р ̈̈̈̈в О. I 995. A nuclear "fossil" of the mitochondrial D-loop and the origin of modern humans. Nature 378:489-92. 